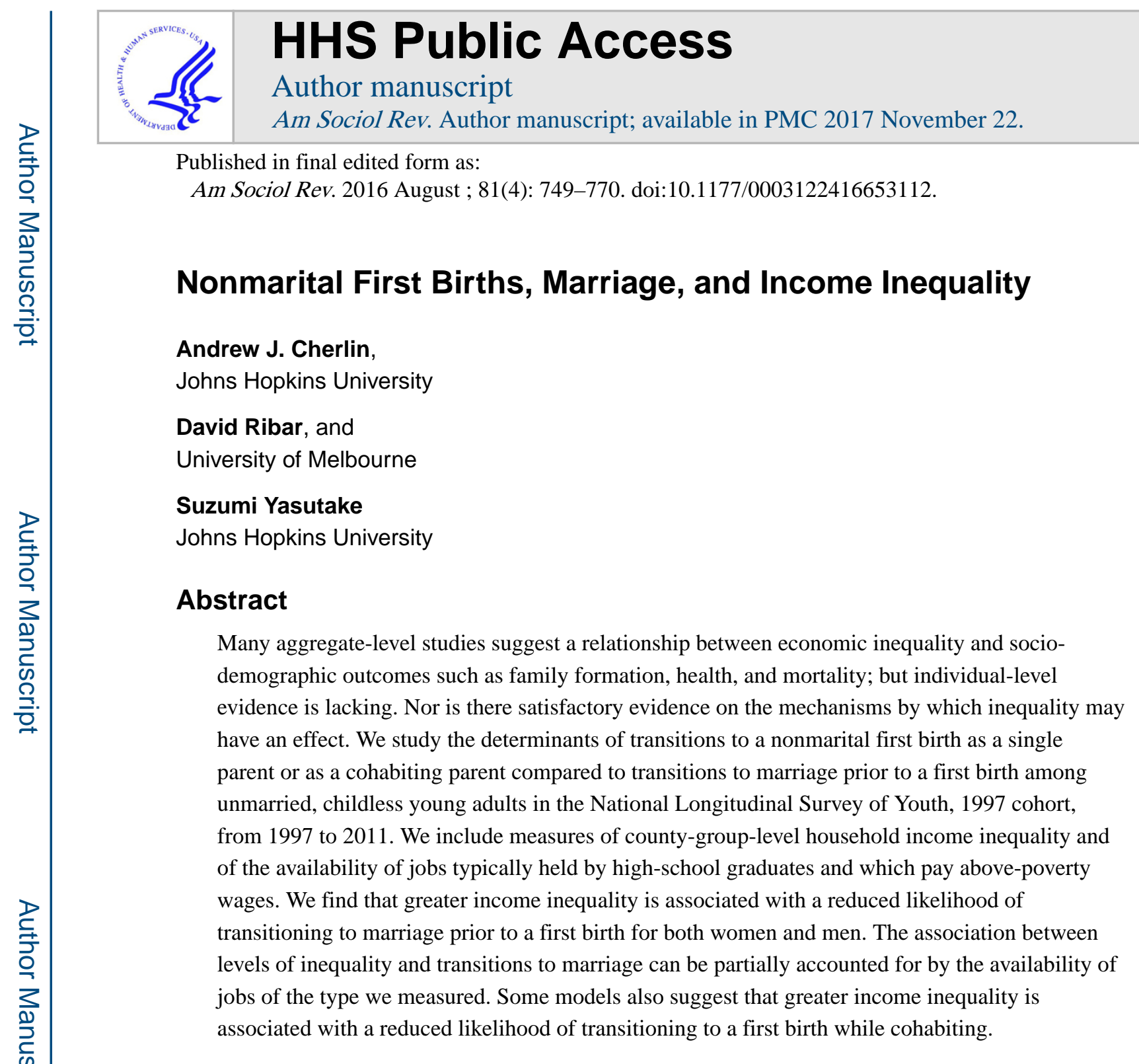

\title{
Keywords
}

Family; inequality; labor market; marriage; nonmarital births

\begin{abstract}
The rise in income inequality in the United States over the past several decades is by now well-known (Piketty and Saez 2003). Its causes are widely thought to include the transformation of the labor market through the computerization of routine work (Kristal 2013) and the offshoring of production (Autor, Dorn and Hanson 2013). Other potential causes include institutional factors such as the decline in the percentage of workers who belong to unions (Western and Rosenfeld 2011) and the decreasing purchasing power of the minimum wage (Card and DiNardo 2002), along with demographic factors such as the increase in single- and cohabiting-parent families (Moller, Alderson and Nielsen 2009). The growth of the financial sector may also have increased inequality by lowering labor's share of national income (Lin and Tomaskovic-Devey 2013). It is still unclear, however, what
\end{abstract}

Corresponding author: Andrew J. Cherlin, Dept. of Sociology, Johns Hopkins University, Baltimore MD 21218. Phone: 410-516-2370. Fax: 410-516-7590. cherlin@jhu.edu. 
effects, if any, rising income inequality has had on personal and family life at the individual level. Although there have been many studies of the social impacts of income inequality from researchers in economics, sociology, political science, and public health, these studies have tended to rely on aggregate data at the cross-national, state, and metropolitan-area level, in which the outcomes are health measures such as obesity rates (Vogli et al. 2014) or mortality rates (McLaughlin, Stokes and Nonoyama 2001); demographic measures such as the percentages married (Loughran 2002) or divorced (Frank, Levine and Dijk 2014); teenage birth rates (Gold et al. 2001); or state voting patterns (Gelman, Kenworthy and Su 2010). An influential book-length treatment argued that higher levels of income inequality cause lower levels of social trust, higher levels of mental illness in women, more drug use, poorer physical health, higher mortality, greater obesity, lower educational attainment, higher teenage birth rates, greater exposure among children to conflict, higher rates of imprisonment, and less social mobility - with all of these conclusions based on crossnational correlations (or state-level correlations within the United States) between the outcome in question and the level of income inequality (Pickett and Wilkinson 2009).

The individual-level evidence in support of these broad conclusions, however, is surprisingly modest. To be sure, income inequality is an aggregate-level concept that must be measured across geographic areas. Yet an old literature in sociology has warned generations of graduate students of the pitfalls of generalizing from ecological correlations to individual behavior (Robinson 1950, Selvin 1958); and the outcomes that are of interest in the inequality debate usually reside in the behavior of individuals. This is not to say that ecological analyses of the influence of income inequality are of no value, but rather that they must be supplemented with studies that examine outcomes on an individual level. In this article we will present individual-level evidence of the association between income inequality and behavior, specifically having a first birth while single or cohabiting versus marrying prior to a first birth.

Moreover, social scientists need to clarify how and why income inequality may be correlated with individual behavior. To have any explanatory value, inequality must be something more than a new label for social and economic disadvantage. There are many possible pathways. Pickett and Wilkinson (2009), for example, argue that inequality increases competition and anxiety over social status, leading to higher chronic stress levels, reduced trust, and an insecure, narcissistic personality. Kearney and Levine (Kearney and Levine 2014a, Kearney and Levine 2014b), in two of the few individual-level national studies, found that that longterm income inequality at the state level was associated with higher levels of nonmarital births among adolescent girls in the National Survey of Family Growth (NSFG) and with dropping out of high school among adolescents in a pooled sample of several national studies. They hypothesized that inequality heightened adolescents' sense of economic marginalization and lowered their perceived sense of becoming economically successful adults, resulting in feelings of economic hopelessness and despair. With respect to early births, Kearney and Levine argue, adolescent girls become discouraged about the prospects for ever succeeding economically, whether through marriage or their own earnings. This dim view of their economic future, according to the authors, lowers the opportunity costs of an early birth. With respect to education, these feelings reduce adolescents' motivation to graduate from high school. 
Anxiety about social status and feelings of economic marginalization are reasonable explanations for the seeming consequences of economic inequality (Edin and Kefalas 2005, Wilson 1987), although neither Pickett and Wilkinson nor Kearney and Levine present direct evidence on an individual level to confirm them. But for adults who are in their twenties and in the process of family formation, the level of income inequality in one's local area also could reflect important variations in employment opportunities. That variation could, in turn, influence patterns of childbearing and partnering, such as whether or not a young adult has a nonmarital first birth. We will argue that with respect to the marital context of a first birth, the apparent effect of local-area income inequality is, in part, a marker for employment opportunities, most notably the proportion of jobs that are in the middle of the labor market. By the latter phrase we mean jobs that are accessible to high-school graduates and that pay above-poverty wages.

Our focus on the middle of the labor market follows for two reasons. First, an established literature in sociology and economics ties marriage to labor market opportunities for young men (Becker 1991; Oppenheimer 1988; Parsons and Bales 1955). ${ }^{1}$ Moreover, several studies show that young women with greater earning potential have higher rates of marriage (McLaughlin and Lichter 1997, Oppenheimer, Blossfeld and Wackerow 1995). In the current era, most of the marriages among adults in their twenties occur to those who do not obtain bachelor's degrees ${ }^{2}$, as we will describe later in this paper. Most are high school graduates, for whom opportunities in the middle of the labor market are relevant.

The second reason for focusing on opportunities in the middle of the labor market is that the percentage of occupations that are in this sector has declined: The share of routine, mediumskilled jobs such as production workers, operatives, and sales personnel has diminished due to the computerization of production, which has replaced workers with automated equipment, and the globalization of production and some services, which has moved work overseas (Autor, Katz and Kearney 2008). The result is that workers with high-school degrees but not bachelor's degrees - and particularly men, who have tended to cluster in these occupations - face a weakened demand for their labor, reduced bargaining power, and decreasing or stagnant wages (Kristal 2013, Western and Rosenfeld 2011). At the same time, the employment of men in low-skilled and generally low-paying jobs in areas such as restaurant work and janitorial services has increased (Autor 2010). The kinds of jobs that a man could hold for a career have diminished, and more of the remaining jobs have taken on a temporary "stopgap" character - casual, short-term, and not part of a career strategy (Kalleberg 2011, Oppenheimer, Kalmijn and Lim 1997). Women have also experienced a decline in middle-skilled employment but, unlike men, they have not increased their share of service occupations; rather, they have increased their share of upper white-collar occupations such as professionals, managers, and technical specialists (Autor 2010).

Using this perspective, we seek to advance our understanding of the relevance of the concept of economic inequality for individual and family life. We will examine the likelihood over

\footnotetext{
${ }_{1}^{1}$ We focus here on different-sex marriage because it is the context in which social norms about family formation have been developed. ${ }^{2}$ By a bachelor's degree we mean a college degree such as a B.A. or B.S. that is designed to be completed in four years but may take longer to attain.
} 
time, among childless and unmarried young adults, of remaining childless and unmarried versus having a nonmarital birth while unpartnered, having a nonmarital birth while cohabiting, or marrying prior to a first birth, We will use a large, well-known, individuallevel dataset, the National Longitudinal Survey of Youth, 1997 Cohort (henceforth NLSY97). We have included information through the 2011 survey wave. The respondents, who were born in 1981 to 1985 and who began to enter their twenties in 2001, are the leading edge of the cohort commonly referred to as the "millennials" (Pew Research Center 2010). We include in our analyses individual characteristics that are plausibly exogenous to a young adult's family formation decisions, such as race and ethnicity, age, parents' educational attainment, and family structure at the start of the observation period. We supplement the individual records with indicators of income inequality, opportunities in the middle of the local labor market, and sex ratios measured at the county level for respondents living in large counties and at the county-group level for respondents living in medium-sized and smaller counties, as well as the unemployment rate measured at the county level for everyone.

To measure inequality, we rely on two widely-used ratios of household income inequality: the ratio of the median household income to the household income at the 10th percentile of the household income distribution (which we will refer to as the "50/10 ratio") and the ratio of income at the 90th percentile to income at the median (the "90/50 ratio"). We first examine the relationship between income inequality and whether an unmarried, childless individual has a first birth without marrying or cohabiting, has a first birth while cohabiting, or marries prior to having a birth. We then examine the hypothesis that the seeming effects of greater inequality reflect, at least in part, a lower supply of the kinds of middle-skilled jobs that pay above-poverty wages and are available to high-school graduates.

\section{Conceptual Model}

Over the past few decades, there has been an increasing divergence by education in the ways that American young adults start new families. Most notably, young adults with bachelor's degrees have continued to wait until after they are married to have their first child, whereas young adults without these credentials have increasingly had one or more children before they married or without ever marrying (Cherlin 2010). Among the mothers of all babies born between 2005 and 2010, just 8 percent of those with a bachelor's degree were single or cohabiting, compared to 41 percent of those with some college education but not a bachelor's degree, 59 percent of those with a high-school degree, and 65 percent of those without a high-school degree (Payne, Manning and Brown 2012). The popular image of nonmarital childbearing is still of adolescents; but fertility among adolescents has dropped substantially, with the birth rate among women age 15-19 reaching repeated lows in recent years (U.S. National Center for Health Statistics 2015). Although teenagers in 1970 accounted for 50 percent of all nonmarital births, by 1999 they accounted for only 29 percent (U.S. National Center for Health Statistics 2000). The largest increase in nonmarital childbearing since 1980 has been among individuals in their twenties who have high-school degrees but not bachelor's degrees: The percentage of mothers with this moderate level of education who were unmarried when they gave birth increased from 14.7 percent in 1980 to 29.7 percent in 2010 (Stykes and Williams 2013). An increase in nonmarital childbearing 
has also occurred since 1980 among persons without high-school degrees (from 27.2 percent to 34.3 percent), but the rate of change has been slower (Stykes and Williams 2013). Thus, we have seen family formation patterns in the United States become more polarized according to education, with nonmarital fertility remaining low among those with bachelor's degrees but growing substantially among those without bachelor's degrees.

We propose a conceptual model of the marital context of first childbirth that rests on two assumptions about the social norms that are relevant to family formation: First, marriage is still a highly-valued status; and it remains, in the abstract, the preferred context for childbearing. Several studies suggest that even as the percentage of the population that is currently married decreases, marriage is still seen as the best basis for family life (Cherlin 2009), even among the low income population (Edin and Kefalas 2005). Second, childbearing outside of marriage, whether in a cohabiting union or living without a partner, is broadly social acceptable. In the 2006-2010 NSFG, 78 percent of women and 70 percent of men strongly agreed or agreed with the statement "It is okay for an unmarried female to have a child." 3 The wide acceptance of nonmarital childbearing is a relatively new development; in the mid-twentieth century, when few children were born outside of marriage, it was highly stigmatized. Its acceptance creates the opportunity for respectable family formation outside of marriage.

In addition, we assume that young adults' transitions to a first birth can in part be modeled using a rational-choice framework. We must acknowledge the limitations of such a model. To be sure, many unmarried women (and nearly all of the research on intentionality is based on studies of women) report that their first pregnancy was unintended. For instance, among women in the 2006-2010 NSFG who had been unmarried at the time of their first pregnancy, 57 percent reported retrospectively that the pregnancy came sooner than they wanted and an additional 19 percent reported that at the time they never wanted to become pregnant. ${ }^{4}$ England (2015) and Reed et al (2014) suggest that women may vary in their contraceptive efficacy - their ability to take the steps necessary to follow through on their contraceptive goals. They also argue that disadvantaged women are less efficacious and therefore more inconsistent in their use of contraception and at higher risk of a pregnancy. Yet others argue that intendedness is more of a continuum than a dichotomy (Bachrach and Newcomer 1999, Edin and Kefalas 2005), with some first pregnancies neither fully intended nor fully unintended. And in the space between the poles, we would claim, women and their partners may respond rationally to incentives and costs. Moreover, even if a first pregnancy to an unmarried woman was completely unintended, it may be reasonable to treat her union status at the time of the birth - living separately, cohabiting, or married - as a decision based in part on rational choices about the costs and benefits of her potential partnership. In addition, a demonstration that an individual's union status at first birth is correlated with her or his local labor market conditions would suggest that the individual is responding rationally to market incentives. The alternative explanation - that unmarried individuals are inherently less efficacious in areas with poorer labor markets than in areas with better labor markets seems implausible.

${ }^{3}$ Authors' calculation from the 2006-2010 National Survey of Family Growth female public data file.

${ }^{4}$ Authors' calculation from the 2006-2010 National Survey of Family Growth female public data file. 
How might the dispersion of incomes - the extent of income inequality - in a local area affect the marriage and childbearing decisions of women and men in that area? Greater income inequality could be a marker of poorer job opportunities in the middle of the local labor market - the sector of the labor market that is directly relevant for moderatelyeducated young adults. In that case, non-college-educated young men who live in local areas with greater income inequality would be expected to experience reduced earning potential, as fewer of them find long-term employment at decent wages and more of them enter the low-skilled, low-wage segment of the labor market. They would be less desirable as marriage partners because of their reduced earning potential. We would predict that their likelihood of marrying would be lower compared to young men who reside in areas with less income inequality, controlling for indicators of socioeconomic and racial/ethnic background as well as for other characteristics of the local area that could be correlated with inequality.

What is more, women may respond to men's labor market opportunities because in choosing a partner, women place greater weight on their partners' potential income than do men. A 2014 national survey found that 78 percent of never-married women said that whether a man had a steady job would be a very important criterion for them in choosing a spouse or partner, whereas just 46 percent of never-married men said it would be important that their spouse or partner have a steady job (Pew Research Center 2014). It is also possible that men who expect to pool two incomes in support of a marriage may respond to women's labor market potential.

Moreover, an increase in men's wage inequality increases the dispersion of men's wages in the local area and therefore increases the gains to women of extending the search for a partner (Gould and Paserman 2003, Loughran 2002, Oppenheimer 1988). With a wider variation in the earnings potential of partners, a woman has more to gain by lengthening the search process (Schwartz 2013). Therefore, greater income inequality, by lengthening the process of searching for a spouse, could directly lower the likelihood that a never-married young adult would transition into marriage in a given time period. As women's financial contributions to marriage become more important to men, it is possible that greater income inequality in an area could lengthen men's searches too. ${ }^{5}$

As to how women would respond to changes in their own labor market opportunities, the literature suggests two contrasting effects (Hannan, Tuma, and Groeneveld 1978, Oppenheimer, Kalmijn, and Lim 1997). Greater opportunities could lead to an "income effect" that increases the chances of marriage because women can offer higher incomes to pool with their partners' incomes. Yet greater opportunities could also lead to an

\footnotetext{
${ }^{5}$ We also recognize that the seeming effect of household income inequality could be due to its correlation with other behavioral or cultural factors. In models not reported here, we included indicators of several of them, including the benefit level of the Temporary Assistance for Needy Families (TANF) program, which is set by each state. The social science literature suggests that TANF benefits may discourage marriage and encourage nonmarital childbearing by providing a source of income to mothers that is not tied to fathers incomes, although the size of the effect is uncertain (Moffitt 1990). Critics of social welfare programs often cite the TANF program as encouraging dependency on government benefits (Murray 2012), although these criticisms have become more muted since a 1996 law imposed substantial work requirements and limited lifetime receipt of federally-funded benefits to five years. To measure the cultural milieu at the state level, we also included indicators such as the extent of state-level restrictions on same-sex unions, the percentage of votes in the most-recent Presidential election in the state that were cast for the Republican candidate, and the level of restrictions on abortion in the state. This last indicator could also directly influence nonmarital childbearing by making the termination of pregnancy more difficult. However, none of these indicators were significant predictors in our models. Nor were indicators of the religion the respondent's parents were raised in.
} 
"independence effect" that decreases the chances of marriage because women could better support themselves and their children independently of marriage. The prevalence of singleparent births is seen in this literature as an independence effect.

Whether and how income inequality and job opportunities would affect the likelihood of a cohabiting birth is indeterminate. Research suggests that cohabitation in the United States is a heterogeneous phenomenon with multiple meanings (Rose-Greenland and Smock 2013). ${ }^{6}$ For some, it serves as a steppingstone to marriage - a trial run that if successful would lead to a wedding. For others, it is more of a low commitment alternative in which the partners preserve their independence. One study that used the NLSY97 data, as we will do, showed that among all first births to cohabiting women, 38 percent of the cohabitations began after the women became pregnant. In contrast, among all first births to married women, 13 percent began after the woman became pregnant (Rackin and Gibson-Davis 2012). Undoubtedly, some couples who begin to cohabit after conception are anticipating a marriage if the relationship proves successful; but others may decide live together for a period of time to get the child off to a good start with little expectation of marriage (Reed 2006). Women's greater job opportunities could increase the likelihood of a cohabiting birth relative to single parenthood by increasing the economic resources of the potential partnership; but they also make single parenthood more feasible for those who wish to remain fully independent of a partner.

\section{Data}

The NLSY97 is a widely-analyzed national study of nearly 9,000 young women and men who were aged 12 to 16 at the time of the initial interview in 1997. They have been reinterviewed annually; we use data through the 2011 wave, when 7,423 were interviewed at ages 26 to 31, with a median age of 28. This age range is old enough that the vast majority of the cohort's lifetime number of nonmarital first births will have been experienced. We make this claim based on data from the 2006-2010 NSFG, which includes women and men age 15 to 44, as presented in Table 1: Of all the first births that had occurred to women in the NSFG who had never married by the time of the birth, 88 percent had occurred before the women reached age 25 , and 96 percent had occurred before they reached age 30 . Of all the first births that had occurred to men in the NSFG who had never married by the time of the birth, 73 percent had occurred before the men reached age 25, and 92 percent had occurred before they reached aged 30. According this benchmark, by the 2011 wave the NLSY97 cohort had aged into being an appropriate source of data for studying the determinants of nonmarital first births.

The NLSY97 study has some advantages over information from other individual-level datasets that have been used to study the union context of fertility, such as the recent waves of the NSFG. First, it is based on annual interviews that obtain information on births and union status contemporaneously rather than through retrospective reports obtained during single interview, which likely improves the accuracy of the sample members' responses to

\footnotetext{
${ }^{6}$ In some Northern and Western European countries, cohabitation sometimes takes the form of a long-term committed relationship that is functionally equivalent to marriage (Goldscheider, Bernhardt and Lappegård 2015). But these long-term stabled arrangements are less common in the United States (Cherlin 2009).
} 
questions about marital status (Hayford and Morgan 2008). Second, it provides information on a birth cohort of individuals as they move through their teenage years and their twenties rather than on a cross-section of individuals at one point in time.

By 2011, 53 percent of women and 41 percent of men in the NLSY97 cohort had reported giving birth to, or fathering, at least one child. Among this group, 59 percent of first births had occurred outside of marriage for both women and men. The percentage of NLSY97 respondents who had ever married by 2011 was lower -48 percent of women and 38 percent of men - a difference that is consistent with data showing that since 1991 the median age at marriage has been higher than the median age at first birth (Arroyo et al. 2012). Relatively few of the cohort members who had attained bachelor's degrees had borne or fathered a first child: 34 percent of women and 23 percent of men. First births were much more common among the non-college-educated: 65 percent of women and 48 percent of men. As a result, college graduates were underrepresented among parents in the NLSY97 through 2011, as is the case nationally among births to young adults under age 30 . For instance, in the 2006-2010 NSFG, the mean age at first birth among women with a high-school degree was 22, compared to 28 for women with a four-year college degree; and a comparable difference by educational attainment existed among men (U.S. National Center for Health Statistics 2012). The analyses we present should be thought of as a study of the marital context of first births in a largely non-college-graduate young adult population. They are, of course, the group that has been more negatively affected by rising economic inequality.

\section{Statistical Model}

For each respondent, we began with the first observation at which she or he had reached age 16 because, by the design of the survey, 16 was the youngest age at which every respondent was observed. We excluded 75 respondents who had given birth prior to the first interview in 1997 because information on their circumstances at the time of the birth is incomplete and an additional 87 who had given birth after 1997 but prior to age 16, as well as 6 who had married prior to age 16. From information obtained at the annual interviews, the NLSY97 staff constructed a monthly history of birth, cohabitation, and marriages. Using these monthly histories, we were able to classify the respondents to be in one of three relationship categories, married, cohabiting, or unpartnered; and in one of two fertility categories, no first birth versus first birth, in each month. Combining this information, we coded each respondent as in one of four states each month: (1) gave birth to or fathered a first child and not cohabiting with, or married to, the other parent, which we will call a single-parent birth; (2) gave birth to or fathered a first child and cohabiting with the other parent, which we will call a cohabiting-parent birth; (3) married but no first birth, which we will call marrying prior to having a first child; or (4) remained unmarried and childless. ${ }^{7}$ A respondent who had transitioned to states one, two, or three since the previous interview was removed from the risk set after that year's interview. Respondents who remained in state four remained in the risk set and were observed at the next interview. These annual observations continued

\footnotetext{
${ }^{7} \mathrm{~A}$ respondent who reported both a birth and the start of a marriage in the same month was considered to have married prior to the birth. We also replicated the analysis using the contemporaneous information collected at the time of the annual interview and only referring to the monthly histories when annual information was incomplete; the results, which are available from the authors, were very similar. In particular, the pattern of associations between income inequality and marriage was nearly identical.
} 
until either the respondent left the sample or the last observation point, 2011, was reached. The result is 42,427 person-year observations for men and 33,625 person-year observations for women of individuals at risk of a nonmarital first birth. Missing values were imputed using the chained equation method to generate 20 imputation data sets, on which the analyses were conducted.

We include cohabiting-parent births as a separate state because much of the increase in nonmarital childbearing in recent decades has been due to the growth in births to unmarried couples who were cohabiting at birth rather than living apart. Between 1980 and 2010, for instance, the increase in mothers who were cohabiting at birth accounted for 64 percent of the total increase in the proportion of mothers who were unmarried at birth (Stykes and Williams 2013). Nevertheless, because our focus is on nonmarital first births, we treat cohabitation and marriage differently. An individual who has married is no longer eligible to have a nonmarital first birth, and is therefore removed from the risk-set whether or not a first birth has occurred. In other words, an individual needed only to marry and not necessarily to have had a first birth to be removed. Marriage is therefore considered an absorbing state from which one cannot exit. But an individual who is cohabiting and childless is still at risk of a nonmarital first birth and is not removed from the risk-set until either a first birth (while still cohabiting or while single) or a marriage occurs. ${ }^{8}$

We estimate the parameters of our four-state model with a multinomial logistic, discretetime hazard model (Allison 1982), based on person-year observations, with standard errors corrected for the clustering of observations within individuals:

$$
\log \left(\frac{p_{\mathrm{ijt}}}{p_{i 4 t}}\right)=\alpha_{j} T_{i t}+\beta_{j} x_{i t}+\gamma_{j} z_{i}+\delta_{j} w_{i t}
$$

Where $j=1$ to 4 with the reference category being state $4 ; i$ indicates the respondent $i ; t$ is a measure of time such that $t=1$ if the respondent is age $16, t=2$ if the respondent is age 17, and so forth through the last interview at which the respondent is observed to be at risk of a nonmarital first birth; $T_{i t}$ is a vector of duration variables for the unmarried, childless spell (based on $t$ ); $x_{i t}$ is a vector of time-varying characteristics of individual $i$ at time $t, z_{i}$ is a vector of time-invariant characteristics of individual $i$, and $w_{i t}$ is a vector of county- or county-group-level indicators for individual $i$ at age $t$. The model was estimated separately for women and men.

The time-varying individual characteristics are:

- Region of residence: Binary variables for North Central, South, and West, with East as the reference category.

\footnotetext{
${ }^{8}$ It is possible that a small number of respondents had their marriages end prior to having a first birth. In addition, one could expand the state-space in ways we have chosen not to pursue. For instance, one could distinguish between cohabiting unions and marriages that were established prior to conception versus those that were established after conceptions, as some descriptive studies have done (Gibson-Davis and Rackin 2014). In this paper, we will not attempt to model a state-space this complex in part because we believe that such as model would make more demands on our data than it can support.
} 
- Year of observation: Binary variables for 2000 to 2004, 2005 to 2007, and 2008 to 2011, with 1997 to 1999 as the reference variable. The Great Recession began in December 2007 (National Bureau of Economic Research 2010).

- Age/duration: a set of dummy variables for each individual age from 16 to 28 or more; by construction, these also account for the baseline duration dependence pattern.

The time invariant individual characteristics are:

- Race/ethnicity: Binary variables for African American, Hispanic, and other, with non-Hispanic white as the reference category. Hispanics and African Americans have substantially higher nonmarital birth rates than do non-Hispanic whites (Sweeney and Raley 2014, U.S. National Center for Health Statistics 2015)

- $\quad$ Structure of respondent's family at the start of the study in 1997: Binary variables for (a) biological parent and stepparent present; and (b) single parent or no parent present; with two-biological-or-adoptive parents as the reference category. Studies suggest that men and women raised by single parents make the transition to parenthood at earlier ages (Hofferth and Goldscheider 2010) and that they are more likely to have children outside of marriage (Carlson, VanOrman and Pilkauskas 2013).

- Parental education: Binary variables for high-school graduate, some college, and college graduate, with no high-school degree as the reference category. We used mother's education if available and, if not, father's education. We take parental education as an indicator of social class background during childhood and adolescence.

We also included key time-varying indicators of the labor market and the sex ratio measured at the county or county-group level. The variables in our analyses include, first, several measures of the labor market:

- Household income inequality: Two ratios comparing incomes at the ninetieth, fiftieth, and tenth percentiles in the distribution of household incomes in the county or county-group of residence: the ratio of the fiftieth percentile to the tenth percentile (50/10 ratio) and the ratio of the ninetieth to the fiftieth percentile (90/50 ratio). Both ratios have been used in the literature on income inequality. Since the mid-1980s, the $90 / 50$ hourly earnings ratio has increased substantially, as earnings of workers at the top of the labor market have pulled away from earnings of workers in the middle and at the bottom. Over the same period, the 50/10 earnings ratio has decreased somewhat for male workers, as the earnings of workers in the middle of the labor market have moved moderately downward toward the earnings of workers at the bottom (Autor, Katz and Kearney 2008). These trends in individual earnings inequality contribute to income inequality at the household level, which we use as the basis for our measures because of our interest in the marital context of first births.

It is not clear which of the two ratios is the most relevant for women and men in their twenties. In their study of adolescent births, Kearney and Levine (2014a) used the 50/10 
ratio. During the early years of the NLSY97 panel, when the educational attainment of the respondents was low, the 50/10 ratio may better reflect the opportunities they perceived. But by 2011, the vast majority of the NLSY97 respondents had graduated from high school and substantial numbers had taken some college courses. They could be thought of as situated in the broad middle of the labor market, and they may look toward individuals in the ninetieth percentile in developing their norms about standards of living. Consequently, both the spread of opportunities in the lower half of the market, as measured by the 50/10 ratio, and the spread of opportunities between the top and middle of the market, as indexed by the 90/50 ratio, could be relevant. Moreover, both ratios could be markers of underlying processes with which they may be correlated. We will present models that use each of the ratios. ${ }^{9}$

The ratios are calculated from the Integrated Public Use Microdata Series (IPUMS) versions of the 2000 Decennial Census and the American Community Surveys for 2005 to 2011 (Ruggles et al. 2010). These datasets provide information for "super" public use microdata areas (super-PUMAs). Super-PUMAs are the smallest geographic areas that are consistently identified across the 2000 IPUMS Census file and the 2005-2011 IPUMS American Community Survey files (U.S. Bureau of the Census 2013). Super-PUMAs are areas with at least 400,000 residents. At the start of the NLSY97 study, 33 percent of the respondents resided in large- or medium-sized counties that were identical in size to one super-PUMA or that could be constructed by combining super-PUMAs. For respondents who resided in these locations, our measure of the local area in 1997 is at the county level. For the remaining 67 percent of respondents, who tended to live in smaller counties, our measure of the local area in 1997 is at the county-group level because the relevant super-PUMA included more than one county. The 2000 values of the income inequality ratios for the super-PUMA were assigned to the years 1997, 1998, 1999, 2000, 2001 and 2002. The 2005 values were assigned to years 2003, 2004, and 2005. From 2006 through 2011, the annual values were assigned.

- $\quad$ Middle-skilled jobs: We used the same IPUMS data to construct gender-specific local area measures of the percentage of employment that is in occupations that tend to be accessible to people who have completed high school or its equivalent but not more than one year of college (whom we refer to as high school graduates) and that tend to pay high proportions of people with those educational credentials above-poverty wages. We define "above poverty" as at least 1.3 times the poverty threshold for a household with two members. That amount was $\$ 19,054$ in 2011, which was the annual equivalent of the gross-income threshold for eligibility in the Supplemental Nutrition Assistance Program (SNAP), formerly known as the Food Stamp program. Thus, we are defining abovepoverty pay as annual, full-time earnings that are sufficient to support the worker and either a spouse or a child without having to receive SNAP benefits.

More specifically, we first pooled the IPUMS data across years to estimate the percentage of civilian wage and salary workers who completed high school but not more than a year of

\footnotetext{
${ }^{9}$ In fact, the two ratios are highly correlated. In 2000, according to the estimates we used, the correlation between the 50/10 and 90/50 ratios was 0.74 . When both were entered into our estimating equations at the same time, neither dominated; rather most of the coefficients were not statistically significant, which probably reflected the high degree of collinearity between the ratios.
} 
college ( 52.2 percent) and the percentage of full-time ( 35 hours per week or more), full-year (50 weeks or more) workers with these educational credentials who earned at least 1.3 times the poverty threshold for a household with two members ( 86.5 percent). Second, we estimated similar cross-year averages of these percentages for each of the three-digit occupations in the IPUMS data and flagged occupations that had above-average proportions of high-school graduates (that is, above 52.2 percent) and also above-average proportions of full-time, full-year high school graduates who were receiving above-poverty pay, as we have defined it (above 86.5 percent). ${ }^{10}$ The flagged occupations conformed to our expectations for middle-skilled jobs: they were mainly in the broad areas of sales, office and clerical work, protective services, production workers, and operatives. Third, we estimated the proportion of workers in the flagged occupations in each year in the counties and countygroups that could be identified using super-PUMA data. Fourth, we produced genderspecific versions of this measure by identifying occupations in which half or more of the employees were men and occupations in which half or more of the employees were women. We then constructed separate measures for the majority-male and majority-female sets of occupations. We did this because of the well-known gender segregation of the work force. Moreover, men's opportunities have been concentrated in the sectors of the economy (e.g., manufacturing) that have been affected more by the automation and globalization of production. Nevertheless, this is a rough distinction because there is an overlap between the occupations women and men typically do. We will refer to these gender-specific variables as the index of middle-skilled jobs for men and the index of middle-skilled jobs for women. Finally, we linked the annual observations of respondents in the NLSY97 to these annual, local-area measures of the proportion of workers in the flagged occupations, using county identifiers from the NLSY97 geocode file.

The result is two gender-specific indicators of the share of employment in the local area that is accessible to high-school graduates and that pays above-poverty wages. The average proportion of employment in all above-poverty-paying, high-school accessible occupations in the IPUMS data is 36.9 percent, with 24.5 percent being jobs in which a majority of the workers were men and 12.4 percent being jobs in which a majority of the workers were women.

- Unemployment: The unemployment rate in the county in each year, which is included at the county-level in the NLSY97 public-release dataset. It is the most widely-used measure of overall local labor market conditions.

- $\quad$ Sex ratio: The IPUMS data were insufficient to calculate local sex ratios for small age groups. We therefore constructed a ratio of the number of men age 15 to 34 in the county divided by the number of women age 15 to 34 in the county, using annual county population estimates data from the U.S. Census Bureau. Recent studies have found substantial rates of intermarriage among Hispanic and Asian young adults, most often to non-Hispanic white partners; and studies have also found increasing but much lower rates of intermarriage among African Americans. For instance Qian and Lichter (2011) reported that among all

${ }^{10}$ The 2000-2011 IPUMS data include consistent occupational coding that is based on a modified version of the Census Bureau's 1990 occupational classification. 
marriages in 2008, 48 percent of U.S.-born Asian women married non-Asians; and 41 percent of U.S.-born Hispanic women married non-Hispanics. In contrast, only 9 percent of U.S.-born black women married non-blacks. Consequently, we created separate sex ratios for non-blacks and for blacks and assigned them to individuals accordingly.

\section{Identification}

The main threat to the identification of the causal effects of labor market characteristics such as employment opportunities in our models is the non-random assignment of NLSY respondents to local labor markets. Respondents who were more (or less) likely to marry prior to a first birth due to unmeasured characteristics may have been more likely during the study to move to new labor markets that provided better employment opportunities. Such movement would create a spurious correlation between labor market opportunities and the marital context of first birth. We cannot eliminate this source of bias, but in order to minimize it, we estimated a counterfactual set of models in which we constrained all respondents to remain in the super-PUMA they resided in at the start of the panel in 1997. We updated the labor market characteristics of an individual's original super-PUMA annually, but we did not allow the individual to move to a new one. Thus, the income inequality and job availability indicators were measured contemporaneously with the outcome measures, but with the counterfactual assumption that the respondent remained in the same region as in 1997. The logic of this counterfactual analysis is that the location of the respondents in 1997, at which time nearly all were living with their parents, could reasonably be taken as exogenous to their subsequent migration decisions. Thus, we are using 1997 location as a type of instrumental variable to predict the labor market conditions an individual is subject to later in the life of the panel. To be sure, this is an imperfect instrument. It is increasingly inaccurate as the panel ages; by 2003 about one-fourth had moved from their original super-PUMA and by 201152 percent had moved. ${ }^{11}$ Moreover, the respondents' parents were not randomly assigned to counties, either. We therefore present equivalent models in which county of residence is unconstrained, which is the usual way in which the data would be analyzed in sociological research; and we compare the two sets of models.

We also limited the individual-level characteristics in our statistical models to those that are plausibly exogenous to the event of conceiving a child: the year in which the observation took place; the respondent's age and race/ethnicity; his or her residence in one of four regions of the nation (which is constrained to the 1997 region in our counterfactual models); the educational attainment of her or his parent; and the family structure he or she experienced at the start of the study in 1997. We did not include the respondent's own enrollment status or educational attainment because these measures are often endogenous to childbearing; for example, young women may drop out of school because they have had a child. Table 2 presents the means and standard deviations of the variables by gender, based

\footnotetext{
${ }^{11}$ According to a Census Bureau report, migration (defined as moving to a new household) peaks among 20-to-24-year olds and remains high for 25-to-29-year-olds (U.S. Bureau of the Census 2015).
} 
on the person-year observations of individuals at risk of a nonmarital first birth, with county of residence unconstrained.

\section{Results}

Table 3 presents the subset of parameters for the labor-market variables and the sex-ratio variable in the models with area of residence constrained to the 1997 location. (The full sets of parameters, which include the individual-level variables that largely serve as controls in our analysis, are presented in Appendix Table 1 for men and Appendix Table 2 for women. 12 ) We present the results separately for the 50/10 and 90/50 ratios. For each ratio, we present the parameters from two models, first (Model 1) without the indices of middleskilled jobs for men and women, and second (Model 2) with these indices included. In Model 1 the following pattern can be seen across both inequality ratios for women and men: Inequality is significantly and negatively related to the log-odds of marriage prior to a first birth. That is to say, childless and unmarried men and women who reside in counties or county-groups with greater household income inequality have a lower likelihood of moving directly into marriage without having a birth beforehand. These results support the salience of levels of local-area economic inequality for marriage.

In addition, women's outcomes are associated with the sex ratio, which is measured in our models as the ratio of men to women in the local area. It is positively associated with transitions to marriage prior to a first birth across both income ratios for women; and it positively associated cohabiting births for women using the 50/10 ratio. The greater the supply of men relative to women, the more likely a woman is to marry before having a first child or to have a birth while cohabiting (as opposed to transitioning to a single-parent birth or remaining childless), a result consistent with the idea that when women are in short supply, they can bargain more effectively for marriage or a partnership prior to childbirth. There are no significant associations with the sex ratio for men. Finally, the county unemployment rate, the most widely-used measure of labor market conditions, is significantly and positively associated with a higher likelihood of transitioning to a singleparent birth for men.

The indices of the availability of middle-skilled jobs with above-poverty earnings in the local area for men and for women allow us to assess the association between conditions in the middle of the labor market and birth and marital transitions. These indices are introduced in Model 2. For both women and men, we find that the greater the availability of middleskilled jobs, the greater is the likelihood of marrying prior to having a first birth. Moreover, the indicators of both women's and men's jobs are significantly associated with marrying for women and men. Once these indices are in the model, the parameters for the association between household income inequality and marriage prior to a first birth are reduced in

\footnotetext{
${ }^{12}$ The significant parameters for the individual-level variables follow expected and well-known patterns. For instance, the log-odds of both a first birth while cohabiting and of marrying prior to a first birth were greater for members of the NLSY97 cohort who were older (recall that all were born between 1981 and 1985), undoubtedly because they had lived further into young adulthood. In addition, the odds of a single-parent birth were higher for blacks and Hispanics, for individuals who were living in single-parent families or stepfamilies at the start of the study, and whose parents had less education. The log-odds of marrying prior to a first birth were lower in the East than in other regions. These results suggest that the basic relationships among individual characteristics and the demographic outcomes in the NLSY97 cohort were working as expected from previous studies.
} 
magnitude and no longer statistically significant. It appears, then, that the negative association between local-area income inequality and marriage prior to a first birth is partially accounted for by the availability of jobs that are accessible to high-school graduates and that pay above-poverty wages to both men and women.

In Table 4 we present the parallel results from the same models with geographical location unconstrained - we use the actual location of the respondents in each year to update labor market characteristics. (The full results are presented in Appendix Table 3 for men and Appendix Table 4 for women.) With respect to the income inequality ratios, and before job availability is entered into the equations (Model 1), greater inequality is negatively associated with marriage prior to a first birth for women and men regardless of which income ratio is included, as was the case in Table 3. In addition, however, greater inequality is also negatively associated with cohabiting-parent births for women and men, using either income ratio. Thus, greater income inequality has a more generalized negative association with transitions out of the initial state of unmarried and childless than in the geographicallyconstrained models.

Once the job indices are added to the equations (Model 2), inequality is no longer significantly associated with the likelihood of marriage prior to a first birth for men; and it is no longer significantly associated with the likelihood of a cohabiting-parent birth for women. But inequality does remain a significant negative predictor of marriage for women. As for the parameters for the job indices, they show a pattern of broad, positive association with all possible transitions out of the initial state of being childless and never married for women: a greater likelihood of a single-parent birth, a cohabiting-parent birth, and of marrying prior to a birth. For men, greater availability of men's jobs is now associated with a greater likelihood of a single-parent birth, regardless of which ratio is used. The significant associations involving the availability of jobs, then, are less closely restricted to marriage than in the geographically-constrained models.

We can use the estimated parameters in Tables 3 and 4 and the standard deviations in Table 2 to obtain a sense of the relative size of the associations between income inequality, middleskilled jobs, and the odds of marrying prior to a first birth. Using models that do not include the job indices, we can calculate that a one standard deviation increase in local area income inequality is associated with a mean 10.3 percent decrease in the odds of marrying prior to having a first child, across the income ratios and the geographically constrained and unconstrained models. ${ }^{13}$ This is the reduction in odds for one person-year; a person who remained childless and unmarried through several years of the study, and who continued to live in the same local area, would accumulate similar decreases in odds each year for the entire period that he or she was at risk of a nonmarital first child. In comparison, the reduction in the odds of marriage that would be expected for living with a single parent or with no parents in 1997 versus living with two biological parents averaged 19.1 percent for men and 10.7 percent for women. Thus, the size of the association with income inequality

\footnotetext{
${ }^{13}$ For instance, from Table 2, the standard deviation of the 50/10 ratio for men is 0.57 . From Table 4, the coefficient for income inequality on marriage for men using the $50 / 10$ ratio is -0.161 . The odds of marriage for men are therefore $\exp [(0.57) *(-0.161)]=$. 912 , which is a 8.8 percent reduction $([1-.912] * 100=8.8)$. The range for men across all models in Tables 3 and 4 was 8.8 to 11.2 percent for men, and 8.6 to 14.7 percent for women.
} 
was about half of the size of the family structure association for men and about as large as the family structure association for women. When middle-skilled jobs indices are entered into the model, we find that a one standard deviation increase in the availability of such jobs for men increases men's odds of marrying prior to having a first child by an average of 16.5 percent. For women, a one standard deviation increase in the availability of middle-skilled jobs for women increases women's odds of marrying prior to a birth by an average of 10.1 percent.

\section{Discussion}

In much of the growing literature on inequality, social and health scientists have drawn conclusions about its consequences based solely on correlations among aggregate-level indicators (e.g., Pickett and Wilkinson 2009). This article provides individual-level evidence on the association between income inequality and events in the life course. Our analyses of the NLSY97 cohort through 2011 demonstrate an association between local-area household income inequality and the marital context of a first birth: whether a young adult has a first child as a single parent or as a cohabiting parent or whether she or he marries prior to having a first birth. In all of the analyses we reported - whether we constrained geographical mobility for a clearer causal interpretation or allowed mobility to be unconstrained, and whether we used a measure of the distribution of household incomes that compared the middle to the bottom or one that compared the top to the middle - our models demonstrated that men and women living in areas with greater income inequality were less likely to marry prior to having a first birth. These are our most robust results.

We also have presented evidence that suggests the relevance of job opportunities for individuals with a moderate level of education. We constructed gender-specific indices of the availability in the local area of jobs that are open to high school graduates and that pay above-poverty wages, which we called middle-skilled jobs. For men and women, the most consistent results across all models were that the greater the availability of men's and women's middle-skilled jobs, the greater was the likelihood of marrying prior to having a first birth. Once the job opportunity indices were in the models, inequality was no longer significantly associated with the transition to marriage in most models. This pattern of findings suggests that the availability of middle-skill jobs that pay above poverty-level wages may account at least part of the seeming effect of income inequality on the marital context of first births. The opposite-direction findings (greater inequality appears to reduce the probability of marrying prior to a first birth, whereas greater job opportunities appear to increase it) were connected for men: The index of jobs for men was negatively correlated with the inequality ratios. ${ }^{14}$ The more unequal the household income distribution was in a local area, the fewer middle-skilled jobs were available for men, and the less likely a man was to marry prior to a birth.

In the models without constraints on residential location (Table 4), the associations with job availability were more diffused across the various transitions, with better job opportunities

${ }^{14}$ Across all local areas and years, the correlations between the index of middle-skilled men's jobs and the household inequality ratios are -0.50 for the $90 / 50$ ratio and -0.35 for the $50 / 10$ ratio. 
associated with a higher likelihood of transitioning not only to marriage but also to cohabiting-parent first births. (And in one model to single-parent births as well.) Thus, the greater availability of mid-level jobs tended to accelerate transitions to marriage prior to a birth and to cohabiting-parent births. For women, the availability of mid-level jobs was less closely linked to local-area inequality: the job index for women was uncorrelated with local area inequality. ${ }^{15}$ Moreover, in some models for women, the associations with inequality persisted even after the job indices were taken into account, that is to say, women who resided in areas with greater inequality remained less likely to marry directly. Perhaps the more persistent association between income inequality and marriage prior to a birth among women, compared to men, reflects the greater search costs of finding a husband in local areas with greater income inequality (Gould and Paserman 2003, Loughran 2002, Oppenheimer 1988). Alternatively, it could reflect the perceived need to continue one's education in order raise one's earning potential.

We would caution that our findings apply mainly to young adults who do not attain bachelor's degrees. They constitute the vast majority of people who have nonmarital first births, and they tend to have most of their children in their twenties (Cherlin, Talbert and Yasutake 2014). As the NLSY97 cohort ages into their thirties, the men and women with bachelor's degrees will marry and have first births in larger numbers. We can predict from other studies that most will marry prior to having a first birth. They will predominantly be employed in the professional, managerial, and technical sectors of the labor market that have not been hit hard by computerization and offshoring. It is therefore not clear that local-area income inequality will be relevant to their decisions about marriage and fertility.

But for the non-college-graduates who tend to initiate family formation in their twenties, income inequality and the polarization of the labor market appear to have marked associations with first childbearing and marriage. The greater the local level of income inequality, the less likely men and women are to marry before having a first child - an association that appears driven in part by the lesser availability of middle-skilled jobs that pay above-poverty wages. These associations held whether we used the 50/10 and 90/50 income inequality ratios. Perhaps it is the perception of inequality throughout the distribution of income that matters for young adults; or perhaps both income inequality ratios are, in part, measuring constructs that are not in our models. We have made some progress in showing that income inequality is related to first births, cohabitation, and marriage on an individual level and that job opportunities are relevant to explaining this relationship. But we still do not fully understand the meaning of economic inequality for family formation among young adults.

\section{Acknowledgments}

This research project was supported by grant number 85-12-08 from the Russell Sage Foundation. Geocode information for the National Longitudinal Survey of Youth, 1997 Cohort, was obtained from the Bureau of Labor Statistics under Letter of Agreement 2265.

${ }^{15}$ The correlations between the index of women's jobs and the household inequality ratios are 0.003 for the 50/10 ratio and -.05 for the 90/50 ratio. 


\section{Appendix}

Appendix Table 1

Full parameter estimates from multinomial logistic hazard models with area of residence fixed as of 1997: MEN: 50/10 90/50 (Reference categories in parentheses)

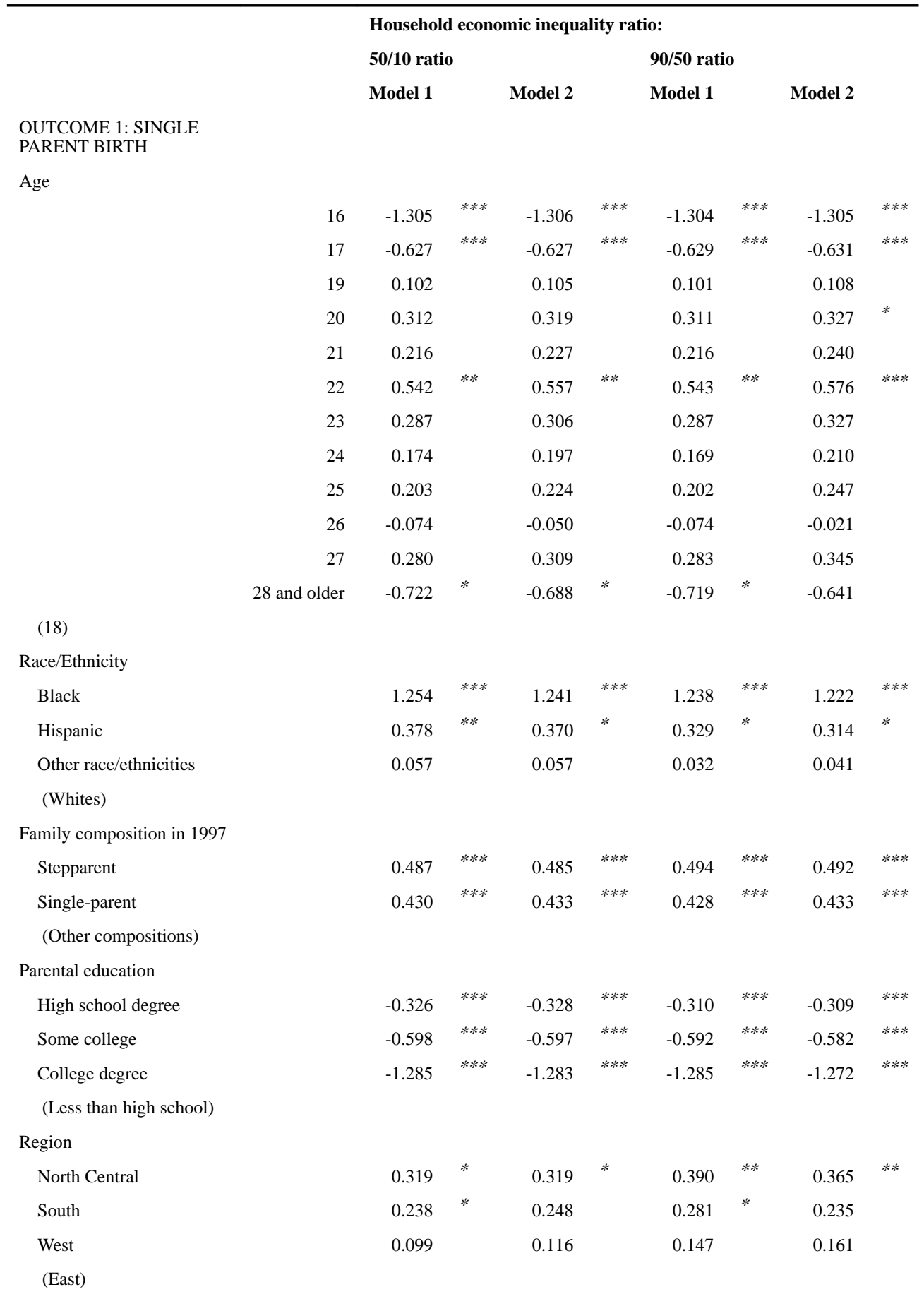




\begin{tabular}{|c|c|c|c|c|c|c|c|c|c|}
\hline & & \multicolumn{8}{|c|}{ Household economic inequality ratio: } \\
\hline & & \multicolumn{4}{|c|}{$50 / 10$ ratio } & \multicolumn{4}{|c|}{$\mathbf{9 0 / 5 0}$ ratio } \\
\hline & & Model 1 & & Model 2 & & Model 1 & & Model 2 & \\
\hline \multicolumn{10}{|l|}{ Year of observation } \\
\hline 2000 to 2004 & & -0.317 & * & -0.316 & * & -0.316 & * & -0.314 & * \\
\hline 2005 to 2007 & & -0.385 & $*$ & -0.374 & & -0.392 & * & -0.380 & \\
\hline 2008 to 2011 & & -0.595 & $*$ & -0.585 & $*$ & -0.573 & $*$ & -0.521 & \\
\hline \multicolumn{10}{|l|}{ (1997 to 1999$)$} \\
\hline \multicolumn{10}{|l|}{ Contextual variables: } \\
\hline Unemployment rate & & 0.042 & $*$ & 0.045 & * & 0.030 & & 0.025 & \\
\hline Sex ratio & & -0.554 & & -0.533 & & -0.333 & & -0.322 & \\
\hline $\begin{array}{l}\text { Household income } \\
\text { inequality ratio }\end{array}$ & & -0.080 & & -0.067 & & 0.150 & & 0.327 & \\
\hline $\begin{array}{l}\text { Index of middle-skilled } \\
\text { jobs - women }\end{array}$ & & & & 3.009 & & & & 5.001 & \\
\hline $\begin{array}{l}\text { Index of middle-skilled } \\
\text { jobs - men }\end{array}$ & & & & 0.551 & & & & 2.053 & \\
\hline Constant & & -3.588 & $* * *$ & -4.223 & $* * *$ & -4.505 & $* * *$ & -6.090 & $* * *$ \\
\hline \multicolumn{10}{|c|}{ OUTCOME 2: COHABITING BIRTH } \\
\hline \multicolumn{10}{|l|}{ Age } \\
\hline & 16 & -2.493 & $* * *$ & -2.491 & $* * *$ & -2.493 & $* * *$ & -2.491 & $* * *$ \\
\hline & 17 & -0.953 & $*$ & -0.954 & $* *$ & -0.952 & * & -0.953 & * \\
\hline & 19 & 0.417 & & 0.423 & & 0.419 & & 0.422 & \\
\hline & 20 & 0.937 & $* * *$ & 0.950 & $* * *$ & 0.940 & $* * *$ & 0.949 & $* * * *$ \\
\hline & 21 & 0.919 & $* * *$ & 0.939 & $* * *$ & 0.922 & $* * *$ & 0.937 & $* * *$ \\
\hline & 22 & 1.053 & $* * *$ & 1.083 & $* * *$ & 1.058 & $* * *$ & 1.080 & $* * *$ \\
\hline & 23 & 1.182 & $* * *$ & 1.215 & $* * *$ & 1.188 & $* * *$ & 1.212 & $* * *$ \\
\hline & 24 & 1.433 & $* * *$ & 1.465 & $* * *$ & 1.442 & $* * *$ & 1.462 & $* * *$ \\
\hline & 25 & 1.517 & $* * *$ & 1.556 & $* * *$ & 1.524 & $* * *$ & 1.552 & $* * *$ \\
\hline & 26 & 1.579 & $* * *$ & 1.627 & $* * *$ & 1.587 & $* * *$ & 1.621 & $* * *$ \\
\hline & 27 & 1.263 & $* * *$ & 1.320 & $* * *$ & 1.273 & $* * *$ & 1.313 & $* * *$ \\
\hline & 28 and older & 1.234 & $* * *$ & 1.306 & $* * *$ & 1.245 & $* * *$ & 1.298 & $* * *$ \\
\hline \multicolumn{10}{|l|}{ (18) } \\
\hline \multicolumn{10}{|l|}{ Race/Ethnicity } \\
\hline Black & & -0.053 & & -0.060 & & -0.055 & & -0.052 & \\
\hline Hispanic & & 0.217 & & 0.246 & & 0.251 & & 0.256 & \\
\hline $\begin{array}{l}\text { Other race/ethnicities } \\
\text { (Whites) }\end{array}$ & & -0.504 & & -0.476 & & -0.494 & & -0.469 & \\
\hline \multicolumn{10}{|l|}{ Family composition in 1997} \\
\hline Stepparent & & 0.672 & $* * *$ & 0.663 & $* * *$ & 0.664 & $* * *$ & 0.662 & $* * *$ \\
\hline $\begin{array}{l}\text { Single-parent } \\
\text { (Other compositions) }\end{array}$ & & 0.567 & $* * *$ & 0.570 & $* * *$ & 0.567 & $* * *$ & 0.569 & $* * *$ \\
\hline \multicolumn{10}{|l|}{ Parental education } \\
\hline High school degree & & -0.370 & $* * *$ & -0.377 & $* * *$ & -0.379 & $* * *$ & -0.380 & $* * *$ \\
\hline
\end{tabular}

Am Sociol Rev. Author manuscript; available in PMC 2017 November 22. 


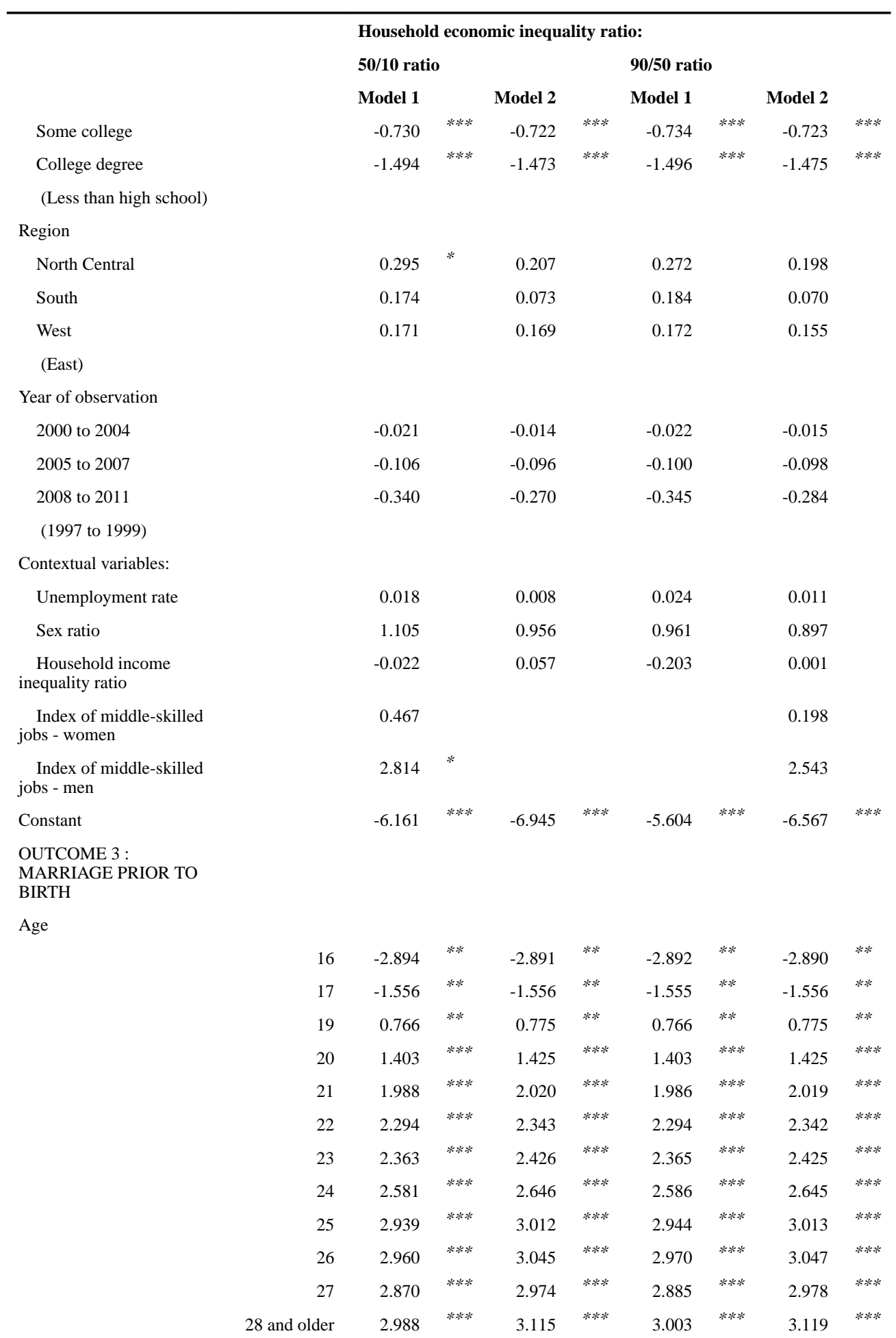

(18)

Race/Ethnicity

Black

$-0.727 \quad * * * \quad-0.743 \quad * * * \quad-0.742 \quad * * * \quad-0.751 \quad * * *$

Am Sociol Rev. Author manuscript; available in PMC 2017 November 22. 


\begin{tabular}{|c|c|c|c|c|c|c|c|c|}
\hline & \multicolumn{8}{|c|}{ Household economic inequality ratio: } \\
\hline & \multicolumn{4}{|c|}{$50 / 10$ ratio } & \multicolumn{4}{|c|}{$\mathbf{9 0 / 5 0}$ ratio } \\
\hline & Model 1 & & Model 2 & & Model 1 & & Model 2 & \\
\hline Hispanic & -0.096 & & -0.080 & & -0.061 & & -0.079 & \\
\hline $\begin{array}{l}\text { Other race/ethnicities } \\
\text { (Whites) }\end{array}$ & -0.776 & $* * *$ & -0.738 & $* * *$ & -0.781 & $* * *$ & -0.742 & $* * *$ \\
\hline \multicolumn{9}{|l|}{ Family composition in 1997} \\
\hline Stepparent & -0.135 & & -0.150 & & -0.142 & & -0.151 & \\
\hline $\begin{array}{l}\text { Single-parent } \\
\text { (Other compositions) }\end{array}$ & -0.209 & $* *$ & -0.202 & $* *$ & -0.209 & $* *$ & -0.201 & $* *$ \\
\hline \multicolumn{9}{|l|}{ Parental education } \\
\hline High school degree & 0.014 & & -0.001 & & 0.003 & & 0.000 & \\
\hline Some college & -0.083 & & -0.073 & & -0.094 & & -0.075 & \\
\hline $\begin{array}{l}\text { College degree } \\
\text { (Less than high school) }\end{array}$ & -0.247 & * & -0.219 & * & -0.253 & $*$ & -0.220 & * \\
\hline \multicolumn{9}{|l|}{ Region } \\
\hline North Central & 0.433 & $* * *$ & 0.334 & $* * *$ & 0.435 & $* * *$ & 0.341 & $* * *$ \\
\hline South & 0.379 & $* * *$ & 0.283 & $* *$ & 0.442 & $* * *$ & 0.301 & $* *$ \\
\hline $\begin{array}{l}\text { West } \\
\text { (East) }\end{array}$ & 0.221 & $*$ & 0.240 & $*$ & 0.260 & * & 0.256 & * \\
\hline \multicolumn{9}{|l|}{ Year of observation } \\
\hline 2000 to 2004 & -0.146 & & -0.135 & & -0.144 & & -0.133 & \\
\hline 2005 to 2007 & -0.327 & & -0.301 & & -0.315 & & -0.298 & \\
\hline $\begin{array}{l}2008 \text { to } 2011 \\
\text { (1997 to } 1999 \text { ) }\end{array}$ & -0.617 & & -0.523 & & -0.607 & & -0.514 & \\
\hline \multicolumn{9}{|l|}{ Contextual variables: } \\
\hline Unemployment rate & 0.018 & & 0.010 & & 0.021 & & 0.009 & \\
\hline Sex ratio & -0.034 & & -0.137 & & -0.085 & & -0.106 & \\
\hline $\begin{array}{l}\text { Household income } \\
\text { inequality ratio }\end{array}$ & -0.195 & $* *$ & -0.086 & & -0.416 & $* *$ & -0.097 & \\
\hline $\begin{array}{l}\text { Index of middle-skilled } \\
\text { jobs - women }\end{array}$ & & & 5.530 & * & & & 5.600 & * \\
\hline $\begin{array}{l}\text { Index of middle-skilled } \\
\text { jobs - men }\end{array}$ & & & 3.843 & $* * *$ & & & 3.924 & $* * *$ \\
\hline Constant & -4.504 & $* * *$ & -6.401 & $* * *$ & -4.210 & $* * *$ & -6.563 & $* * *$ \\
\hline $\begin{array}{l}* \\
\mathrm{p}<.05 \\
* * \\
\mathrm{p}<.01 \\
* * * \\
\mathrm{p}<.001 \text { (two-tailed tests) }\end{array}$ & & & & & & & & \\
\hline
\end{tabular}

Am Sociol Rev. Author manuscript; available in PMC 2017 November 22. 


\section{Appendix Table 2}

Full parameter estimates from multinomial logistic hazard models with area of residence fixed as of 1997: WOMEN. 50/10 90/50 (Reference categories in parentheses)

\begin{tabular}{|c|c|c|c|c|c|c|c|c|c|}
\hline \multirow{4}{*}{$\begin{array}{l}\text { OUTCOME 1: SINGLE } \\
\text { PARENT BIRTH }\end{array}$} & & \multicolumn{8}{|c|}{ Household economic inequality ratio: } \\
\hline & & \multicolumn{4}{|c|}{$50 / 10$ ratio } & \multicolumn{4}{|c|}{$90 / 50$ ratio } \\
\hline & & \multicolumn{2}{|l|}{ Model 1} & \multicolumn{2}{|l|}{ Model 2} & \multicolumn{2}{|l|}{ Model 1} & \multicolumn{2}{|l|}{ Model 2} \\
\hline & & & & & & & & & \\
\hline \multicolumn{10}{|l|}{ Age } \\
\hline & 16 & -0.535 & $* * *$ & -0.536 & $* * *$ & -0.535 & $* * *$ & -0.536 & $* * *$ \\
\hline & 17 & -0.260 & & -0.262 & & -0.261 & & -0.262 & \\
\hline & 19 & 0.176 & & 0.184 & & 0.178 & & 0.184 & \\
\hline & 20 & 0.247 & & 0.265 & $*$ & 0.253 & & 0.265 & $*$ \\
\hline & 21 & 0.221 & & 0.246 & & 0.226 & & 0.245 & \\
\hline & 22 & -0.037 & & -0.003 & & -0.028 & & -0.002 & \\
\hline & 23 & -0.147 & & -0.104 & & -0.133 & & -0.102 & \\
\hline & 24 & -0.269 & & -0.228 & & -0.252 & & -0.225 & \\
\hline & 25 & -0.424 & & -0.377 & & -0.408 & & -0.376 & \\
\hline & 26 & -0.657 & $*$ & -0.597 & $*$ & -0.637 & $*$ & -0.595 & $*$ \\
\hline & 27 & -0.316 & & -0.244 & & -0.293 & & -0.242 & \\
\hline & 28 and older & -1.317 & $* * *$ & -1.231 & $* * *$ & -1.290 & $* * *$ & -1.228 & $* * *$ \\
\hline \multicolumn{10}{|l|}{ (18) } \\
\hline \multicolumn{10}{|l|}{ Race/Ethnicity } \\
\hline Black & & 0.955 & $* * *$ & 0.951 & $* * *$ & 0.953 & $* * *$ & 0.949 & $* * *$ \\
\hline Hispanic & & 0.684 & $* * *$ & 0.706 & $* * *$ & 0.704 & $* * *$ & 0.711 & $* * *$ \\
\hline Other race/ethnicities & & 0.104 & & 0.110 & & 0.098 & & 0.106 & \\
\hline \multicolumn{10}{|l|}{ (Whites) } \\
\hline \multicolumn{10}{|c|}{ Family composition in 1997} \\
\hline Stepparent & & 0.543 & $* * *$ & 0.533 & $* * *$ & 0.541 & $* * *$ & 0.534 & $* * *$ \\
\hline Single-parent & & 0.603 & $* * *$ & 0.599 & $* * *$ & 0.603 & $* * *$ & 0.599 & $* * *$ \\
\hline \multicolumn{10}{|l|}{ (Other compositions) } \\
\hline \multicolumn{10}{|l|}{ Parental education } \\
\hline High school degree & & -0.392 & $* * *$ & -0.393 & $* * *$ & -0.400 & $* * *$ & -0.396 & $* * *$ \\
\hline Some college & & -0.703 & $* * *$ & -0.691 & $* * *$ & -0.708 & $* * *$ & -0.694 & $* * *$ \\
\hline College degree & & -1.340 & $* * *$ & -1.321 & $* * *$ & -1.341 & $* * *$ & -1.323 & $* * *$ \\
\hline \multicolumn{10}{|l|}{ (Less than high school) } \\
\hline \multicolumn{10}{|l|}{ Region } \\
\hline North Central & & 0.192 & & 0.143 & & 0.179 & & 0.146 & \\
\hline South & & 0.183 & & 0.133 & & 0.197 & $*$ & 0.146 & \\
\hline West & & -0.163 & & -0.147 & & -0.144 & & -0.138 & \\
\hline
\end{tabular}




\begin{tabular}{|c|c|c|c|c|c|c|c|c|c|}
\hline & & \multicolumn{8}{|c|}{ Household economic inequality ratio: } \\
\hline & & \multicolumn{4}{|c|}{$50 / 10$ ratio } & \multicolumn{4}{|c|}{$\mathbf{9 0 / 5 0}$ ratio } \\
\hline & & Model 1 & & Model 2 & & Model 1 & & Model 2 & \\
\hline \multicolumn{10}{|l|}{ Year of observation } \\
\hline 2000 to 2004 & & -0.047 & & -0.046 & & -0.047 & & -0.046 & \\
\hline 2005 to 2007 & & -0.019 & & -0.009 & & -0.011 & & -0.007 & \\
\hline 2008 to 2011 & & 0.093 & & 0.138 & & 0.092 & & 0.133 & \\
\hline \multicolumn{10}{|l|}{ (1997 to 1999 ) } \\
\hline \multicolumn{10}{|l|}{ Contextual variables: } \\
\hline Unemployment rate & & 0.009 & & 0.002 & & 0.012 & & 0.004 & \\
\hline Sex ratio & & -0.394 & & -0.469 & & -0.449 & & -0.475 & \\
\hline $\begin{array}{l}\text { Household income } \\
\text { inequality ratio }\end{array}$ & & -0.072 & & -0.029 & & -0.236 & & -0.098 & \\
\hline $\begin{array}{l}\text { Index of middle-skilled } \\
\text { jobs - women }\end{array}$ & & & & 2.786 & & & & 2.522 & \\
\hline $\begin{array}{l}\text { Index of middle-skilled } \\
\text { jobs - men }\end{array}$ & & & & 1.947 & & & & 1.731 & \\
\hline Constant & & -3.029 & $* * *$ & -3.909 & $* * *$ & -2.684 & $* * *$ & -3.699 & $* * *$ \\
\hline \multicolumn{10}{|l|}{$\begin{array}{l}\text { OUTCOME 2: } \\
\text { COHABITING BIRTH }\end{array}$} \\
\hline \multicolumn{10}{|l|}{ Age } \\
\hline & 16 & -1.536 & $* * *$ & -1.537 & $* * *$ & -1.536 & $* * *$ & -1.537 & $* * *$ \\
\hline & 17 & -0.524 & $*$ & -0.526 & $*$ & -0.524 & * & -0.525 & $*$ \\
\hline & 19 & 0.456 & $* *$ & 0.467 & $* *$ & 0.458 & $* *$ & 0.467 & $* *$ \\
\hline & 20 & 0.441 & $*$ & 0.464 & $*$ & 0.446 & * & 0.464 & $*$ \\
\hline & 21 & 0.496 & $*$ & 0.530 & $* *$ & 0.500 & $*$ & 0.529 & $* *$ \\
\hline & 22 & 0.168 & & 0.215 & & 0.176 & & 0.214 & \\
\hline & 23 & 0.675 & $* *$ & 0.732 & $* * *$ & 0.687 & $* *$ & 0.732 & $* * *$ \\
\hline & 24 & -0.038 & & 0.015 & & -0.022 & & 0.017 & \\
\hline & 25 & 0.038 & & 0.099 & & 0.052 & & 0.099 & \\
\hline & 26 & -0.049 & & 0.029 & & -0.032 & & 0.028 & \\
\hline & 27 & -0.380 & & -0.285 & & -0.356 & & -0.284 & \\
\hline & 28 and older & -0.096 & & 0.018 & & -0.068 & & 0.018 & \\
\hline \multicolumn{10}{|l|}{ (18) } \\
\hline \multicolumn{10}{|l|}{ Race/Ethnicity } \\
\hline Black & & -0.163 & & -0.168 & & -0.164 & & -0.167 & \\
\hline Hispanic & & 0.303 & $*$ & 0.331 & * & 0.331 & * & 0.340 & * \\
\hline Other race/ethnicities & & -0.124 & & -0.116 & & -0.133 & & -0.121 & \\
\hline \multicolumn{10}{|l|}{ (Whites) } \\
\hline \multicolumn{10}{|l|}{ Family composition in 1997} \\
\hline Stepparent & & 0.743 & $* * *$ & 0.731 & $* * *$ & 0.740 & $* * *$ & 0.731 & $* * *$ \\
\hline Single-parent & & 0.582 & $* * *$ & 0.576 & $* * *$ & 0.580 & $* * *$ & 0.576 & $* * *$ \\
\hline \multicolumn{10}{|l|}{ (Other compositions) } \\
\hline \multicolumn{10}{|l|}{ Parental education } \\
\hline High school degree & & -0.425 & $* * *$ & -0.430 & $* * *$ & -0.439 & $* * *$ & -0.436 & $* * *$ \\
\hline
\end{tabular}

Am Sociol Rev. Author manuscript; available in PMC 2017 November 22. 


\begin{tabular}{|c|c|c|c|c|c|c|c|c|c|}
\hline & & \multicolumn{8}{|c|}{ Household economic inequality ratio: } \\
\hline & & \multicolumn{4}{|c|}{$50 / 10$ ratio } & \multicolumn{4}{|c|}{$90 / 50$ ratio } \\
\hline & & Model 1 & & Model 2 & & Model 1 & & Model 2 & \\
\hline Some college & & -0.744 & $* * *$ & -0.729 & $* * *$ & -0.752 & $* * *$ & -0.734 & *** \\
\hline $\begin{array}{l}\text { College degree } \\
\text { (Less than high school) }\end{array}$ & & -1.663 & $* * *$ & -1.635 & $* * *$ & -1.666 & $* * *$ & -1.640 & $* * *$ \\
\hline \multicolumn{10}{|l|}{ Region } \\
\hline North Central & & 0.058 & & -0.018 & & 0.043 & & -0.015 & \\
\hline South & & 0.002 & & -0.073 & & 0.030 & & -0.052 & \\
\hline $\begin{array}{l}\text { West } \\
\text { (East) }\end{array}$ & & 0.017 & & 0.038 & & 0.049 & & 0.049 & \\
\hline \multicolumn{10}{|l|}{ Year of observation } \\
\hline 2000 to 2004 & & 0.018 & & 0.021 & & 0.016 & & 0.020 & \\
\hline 2005 to 2007 & & 0.211 & & 0.229 & & 0.218 & & 0.231 & \\
\hline $\begin{array}{l}2008 \text { to } 2011 \\
\text { (1997 to } 1999)\end{array}$ & & 0.444 & & 0.513 & & 0.444 & & 0.506 & \\
\hline \multicolumn{10}{|l|}{ Contextual variables: } \\
\hline Unemployment rate & & -0.018 & & -0.027 & & -0.015 & & -0.024 & \\
\hline Sex ratio & & 1.273 & * & 1.211 & & 1.186 & & 1.186 & \\
\hline $\begin{array}{l}\text { Household income } \\
\text { inequality ratio }\end{array}$ & & -0.103 & & -0.031 & & -0.345 & & -0.140 & \\
\hline $\begin{array}{l}\text { Index of middle-skilled } \\
\text { jobs - women }\end{array}$ & & & & 4.225 & & & & 3.969 & \\
\hline $\begin{array}{l}\text { Index of middle-skilled } \\
\text { jobs - men }\end{array}$ & & & & 2.927 & $*$ & & & 2.605 & \\
\hline Constant & & -4.747 & $* * *$ & -6.155 & $* * *$ & -4.216 & $* * *$ & -5.810 & $* * *$ \\
\hline \multicolumn{10}{|l|}{$\begin{array}{l}\text { OUTCOME } 3 \text { : } \\
\text { MARRIAGE PRIOR TO } \\
\text { BIRTH }\end{array}$} \\
\hline \multicolumn{10}{|l|}{ Age } \\
\hline & 16 & -2.624 & $* * *$ & -2.623 & $* * *$ & -2.623 & $* * *$ & -2.622 & $* * *$ \\
\hline & 17 & -0.966 & $* * *$ & -0.967 & $* * *$ & -0.967 & $* * *$ & -0.967 & $* * *$ \\
\hline & 19 & 0.734 & $* * *$ & 0.745 & $* * *$ & 0.735 & $* * *$ & 0.745 & $* * *$ \\
\hline & 20 & 0.992 & $* * *$ & 1.018 & $* * *$ & 0.995 & $* * *$ & 1.018 & $* * *$ \\
\hline & 21 & 1.382 & $* * *$ & 1.420 & $* * *$ & 1.384 & $* * *$ & 1.420 & $* * *$ \\
\hline & 22 & 1.242 & $* * *$ & 1.293 & $* * *$ & 1.246 & $* * *$ & 1.293 & $* * *$ \\
\hline & 23 & 1.577 & $* * *$ & 1.639 & $* * *$ & 1.584 & $* * *$ & 1.639 & $* * *$ \\
\hline & 24 & 1.466 & $* * *$ & 1.525 & $* * *$ & 1.474 & $* * *$ & 1.526 & $* * *$ \\
\hline & 25 & 1.809 & $* * *$ & 1.870 & $* * *$ & 1.817 & $* * *$ & 1.872 & **** \\
\hline & 26 & 1.687 & $* * *$ & 1.766 & $* * *$ & 1.699 & $* * *$ & 1.769 & $* * *$ \\
\hline & 27 & 1.814 & $* * *$ & 1.909 & $* * *$ & 1.830 & $* * *$ & 1.913 & $* * *$ \\
\hline & 28 and older & 1.919 & $* * *$ & 2.028 & $* * *$ & 1.938 & $* * *$ & 2.032 & $* * *$ \\
\hline
\end{tabular}

Race/Ethnicity

Black

$-1.081 \quad * * * \quad-1.096 \quad * * * \quad-1.084 \quad * * * \quad-1.101 \quad * * *$

Am Sociol Rev. Author manuscript; available in PMC 2017 November 22. 


\begin{tabular}{|c|c|c|c|c|c|c|c|c|}
\hline & \multicolumn{8}{|c|}{ Household economic inequality ratio: } \\
\hline & \multicolumn{4}{|c|}{$50 / 10$ ratio } & \multicolumn{4}{|c|}{$\mathbf{9 0 / 5 0}$ ratio } \\
\hline & Model 1 & & Model 2 & & Model 1 & & Model 2 & \\
\hline Hispanic & -0.186 & & -0.165 & & -0.166 & & -0.163 & \\
\hline $\begin{array}{l}\text { Other race/ethnicities } \\
\text { (Whites) }\end{array}$ & -0.655 & $* * *$ & -0.644 & $* * *$ & -0.659 & $* * *$ & -0.647 & $* * *$ \\
\hline \multicolumn{9}{|l|}{ Family composition in 1997} \\
\hline Stepparent & 0.042 & & 0.031 & & 0.045 & & 0.035 & \\
\hline $\begin{array}{l}\text { Single-parent } \\
\text { (Other compositions) }\end{array}$ & -0.118 & & -0.127 & & -0.118 & & -0.126 & \\
\hline \multicolumn{9}{|l|}{ Parental education } \\
\hline High school degree & -0.148 & & -0.162 & & -0.161 & & -0.164 & \\
\hline Some college & -0.261 & $* *$ & -0.251 & * & -0.269 & $* *$ & -0.253 & * \\
\hline $\begin{array}{l}\text { College degree } \\
\text { (Less than high school) }\end{array}$ & -0.355 & $* * *$ & -0.335 & $* * *$ & -0.360 & $* * *$ & -0.336 & $* * *$ \\
\hline \multicolumn{9}{|l|}{ Region } \\
\hline North Central & 0.359 & $* * *$ & 0.301 & $* *$ & 0.362 & $* * *$ & 0.314 & $* *$ \\
\hline South & 0.573 & $* * *$ & 0.530 & $* * *$ & 0.618 & $* * *$ & 0.557 & $* * *$ \\
\hline $\begin{array}{l}\text { West } \\
\text { (East) }\end{array}$ & 0.219 & * & 0.243 & $*$ & 0.256 & $* *$ & 0.266 & $* *$ \\
\hline \multicolumn{9}{|l|}{ Year of observation } \\
\hline 2000 to 2004 & -0.195 & & -0.189 & & -0.196 & & -0.189 & \\
\hline 2005 to 2007 & -0.154 & & -0.125 & & -0.149 & & -0.124 & \\
\hline $\begin{array}{l}2008 \text { to } 2011 \\
\text { (1997 to } 1999)\end{array}$ & -0.329 & & -0.254 & & -0.324 & & -0.250 & \\
\hline \multicolumn{9}{|l|}{ Contextual variables: } \\
\hline Unemployment rate & 0.012 & & 0.008 & & 0.013 & & 0.007 & \\
\hline Sex ratio & 1.416 & $* *$ & 1.376 & $* *$ & 1.420 & $* *$ & 1.411 & $* *$ \\
\hline $\begin{array}{l}\text { Household income } \\
\text { inequality ratio }\end{array}$ & -0.133 & * & -0.082 & & -0.309 & $*$ & -0.129 & \\
\hline $\begin{array}{l}\text { Index of middle-skilled } \\
\text { jobs - women }\end{array}$ & & & 6.965 & $* *$ & & & 6.864 & $* *$ \\
\hline $\begin{array}{l}\text { Index of middle-skilled } \\
\text { jobs - men }\end{array}$ & & & 2.579 & $* * *$ & & & 2.506 & $* *$ \\
\hline Constant & -4.910 & $* * *$ & -6.583 & $* * *$ & -4.686 & $* * *$ & -6.601 & $* * *$ \\
\hline $\begin{array}{l}* \\
\mathrm{p}<.05 \\
* * \\
\mathrm{p}<.01 \\
* * * \\
\mathrm{p}<.001 \text { (two-tailed tests) }\end{array}$ & & & & & & & & \\
\hline
\end{tabular}

Am Sociol Rev. Author manuscript; available in PMC 2017 November 22. 


\section{Appendix Table 3}

Full parameter estimates from multinomial logistic hazard models with area of residence unconstrained: MEN. 50/10 90/50 (Reference categories in parentheses)

\begin{tabular}{|c|c|c|c|c|c|c|c|c|c|}
\hline \multirow{4}{*}{$\begin{array}{l}\text { OUTCOME 1: SINGLE } \\
\text { PARENT BIRTH }\end{array}$} & & \multicolumn{8}{|c|}{ Household economic inequality ratio: } \\
\hline & & \multicolumn{4}{|c|}{$50 / 10$ ratio } & \multicolumn{4}{|c|}{$\mathbf{9 0 / 5 0}$ ratio } \\
\hline & & \multicolumn{2}{|l|}{ Model 1} & \multicolumn{2}{|l|}{ Model 2} & \multicolumn{2}{|l|}{ Model 1} & \multicolumn{2}{|l|}{ Model 2} \\
\hline & & & & & & & & & \\
\hline \multicolumn{10}{|l|}{ Age } \\
\hline & 16 & -1.318 & $* * *$ & -1.318 & $* * *$ & -1.316 & $* * *$ & -1.315 & $* * *$ \\
\hline & 17 & -0.629 & $* * *$ & -0.631 & $* * *$ & -0.631 & $* * *$ & -0.635 & $* * *$ \\
\hline & 19 & 0.100 & & 0.108 & & 0.099 & & 0.111 & \\
\hline & 20 & 0.304 & & 0.323 & * & 0.302 & & 0.329 & * \\
\hline & 21 & 0.200 & & 0.230 & & 0.197 & & 0.243 & \\
\hline & 22 & 0.526 & $* *$ & 0.567 & $* *$ & 0.522 & $* *$ & 0.585 & $* * *$ \\
\hline & 23 & 0.275 & & 0.325 & & 0.270 & & 0.346 & \\
\hline & 24 & 0.173 & & 0.222 & & 0.166 & & 0.236 & \\
\hline & 25 & 0.193 & & 0.245 & & 0.191 & & 0.273 & \\
\hline & 26 & -0.092 & & -0.028 & & -0.092 & & 0.007 & \\
\hline & 27 & 0.263 & & 0.339 & & 0.258 & & 0.374 & \\
\hline & 28 and older & -0.754 & $*$ & -0.667 & & -0.753 & $*$ & -0.615 & \\
\hline \multicolumn{10}{|l|}{ (18) } \\
\hline \multicolumn{10}{|l|}{ Race/Ethnicity } \\
\hline Black & & 1.234 & $* * *$ & 1.222 & $* * *$ & 1.229 & $* * *$ & 1.212 & $* * *$ \\
\hline Hispanic & & 0.362 & $*$ & 0.385 & $* *$ & 0.322 & $*$ & 0.330 & $*$ \\
\hline Other race/ethnicities & & 0.050 & & 0.063 & & 0.036 & & 0.057 & \\
\hline (Whites) & & & & & & & & & \\
\hline \multicolumn{10}{|c|}{ Family composition in 1997} \\
\hline Stepparent & & 0.494 & $* * *$ & 0.489 & $* * *$ & 0.503 & $* * *$ & 0.504 & $* * *$ \\
\hline Single-parent & & 0.430 & $* * *$ & 0.432 & $* * *$ & 0.431 & $* * *$ & 0.438 & $* * *$ \\
\hline (Other compositions) & & & & & & & & & \\
\hline \multicolumn{10}{|l|}{ Parental education } \\
\hline High school degree & & -0.315 & $* * *$ & -0.310 & $* * *$ & -0.310 & $* * *$ & -0.299 & $* * *$ \\
\hline Some college & & -0.582 & $* * *$ & -0.566 & $* * *$ & -0.582 & $* * *$ & -0.553 & $* * *$ \\
\hline College degree & & -1.273 & $* * *$ & -1.245 & $* * *$ & -1.280 & $* * *$ & -1.239 & $* * *$ \\
\hline (Less than high school) & & & & & & & & & \\
\hline \multicolumn{10}{|l|}{ Region } \\
\hline North Central & & 0.359 & $* *$ & 0.307 & * & 0.417 & $* *$ & 0.343 & $*$ \\
\hline South & & 0.272 & * & 0.212 & & 0.291 & $*$ & 0.153 & \\
\hline West & & 0.057 & & 0.070 & & 0.082 & & 0.085 & \\
\hline
\end{tabular}

Am Sociol Rev. Author manuscript; available in PMC 2017 November 22. 


\begin{tabular}{|c|c|c|c|c|c|c|c|c|c|}
\hline & & \multicolumn{8}{|c|}{ Household economic inequality ratio: } \\
\hline & & \multicolumn{4}{|c|}{$50 / 10$ ratio } & \multicolumn{4}{|c|}{$90 / 50$ ratio } \\
\hline & & Model 1 & & Model 2 & & Model 1 & & Model 2 & \\
\hline \multicolumn{10}{|l|}{ Year of observation } \\
\hline 2000 to 2004 & & -0.325 & $*$ & -0.320 & * & -0.326 & * & -0.320 & $*$ \\
\hline 2005 to 2007 & & -0.368 & & -0.351 & & -0.384 & & -0.372 & \\
\hline 2008 to 2011 & & -0.670 & $*$ & -0.604 & * & -0.665 & * & -0.553 & * \\
\hline \multicolumn{10}{|l|}{ (1997 to 1999$)$} \\
\hline \multicolumn{10}{|l|}{ Contextual variables: } \\
\hline Unemployment rate & & 0.069 & $* * *$ & 0.064 & $* *$ & 0.059 & $* *$ & 0.042 & \\
\hline Sex ratio & & -0.342 & & -0.430 & & -0.185 & & -0.264 & \\
\hline $\begin{array}{l}\text { Household income } \\
\text { inequality ratio }\end{array}$ & & -0.004 & & 0.046 & & 0.240 & & 0.576 & $* *$ \\
\hline $\begin{array}{l}\text { Index of middle-skilled } \\
\text { jobs - women }\end{array}$ & & & & 3.484 & & & & 6.001 & $*$ \\
\hline $\begin{array}{l}\text { Index of middle-skilled } \\
\text { jobs - men }\end{array}$ & & & & 2.294 & * & & & 4.180 & $* *$ \\
\hline Constant & & -4.267 & $* * *$ & -5.346 & $* * *$ & -5.029 & $* * *$ & -7.471 & $* * *$ \\
\hline \multicolumn{10}{|l|}{$\begin{array}{l}\text { OUTCOME 2: } \\
\text { COHABITING BIRTH }\end{array}$} \\
\hline \multicolumn{10}{|l|}{ Age } \\
\hline & 16 & -2.495 & $* * *$ & -2.494 & $* * *$ & -2.494 & $* * *$ & -2.493 & $* * *$ \\
\hline & 17 & -0.952 & * & -0.953 & * & -0.951 & * & -0.953 & * \\
\hline & 19 & 0.420 & & 0.423 & & 0.420 & & 0.423 & \\
\hline & 20 & 0.942 & $* * *$ & 0.951 & $* * *$ & 0.945 & $* * *$ & 0.951 & $* * *$ \\
\hline & 21 & 0.926 & $* * *$ & 0.940 & $* * *$ & 0.930 & $* * *$ & 0.939 & $* * *$ \\
\hline & 22 & 1.060 & $* * *$ & 1.079 & $* * *$ & 1.067 & $* * *$ & 1.080 & $* * *$ \\
\hline & 23 & 1.193 & $* * *$ & 1.215 & $* * *$ & 1.202 & $* * *$ & 1.217 & $* * *$ \\
\hline & 24 & 1.446 & $* * *$ & 1.465 & $* * *$ & 1.457 & $* * *$ & 1.468 & $* * *$ \\
\hline & 25 & 1.528 & $* * *$ & 1.555 & $* * *$ & 1.538 & $* * *$ & 1.555 & $* * *$ \\
\hline & 26 & 1.584 & $* * *$ & 1.619 & $* * *$ & 1.601 & $* * *$ & 1.623 & $* * *$ \\
\hline & 27 & 1.271 & $* * *$ & 1.310 & $* * *$ & 1.293 & $* * *$ & 1.317 & $* * *$ \\
\hline & 28 and older & 1.236 & $* * *$ & 1.282 & $* * *$ & 1.259 & $* * *$ & 1.289 & $* * *$ \\
\hline
\end{tabular}

(18)

Race/Ethnicity

Black

Hispanic

Other race/ethnicities

\begin{tabular}{|c|c|c|c|c|c|c|}
\hline-0.080 & & -0.080 & & -0.104 & & -0.100 \\
\hline 0.269 & * & 0.302 & * & 0.305 & $*$ & 0.322 \\
\hline-0.471 & & -0.447 & & -0.485 & & -0.464 \\
\hline
\end{tabular}

(Whites)

Family composition in 1997

Stepparent

Single-parent

28 and older

1.236

1.282

$$
-0.447
$$

0.664 **
0.562

0.657

$0.564 * * *$

$0.654 * * *$

$0.559 * *$

$0.652 * * *$

(Other compositions)

Parental education

High school degree
$-0.395 * * *$

$-0.396$

Am Sociol Rev. Author manuscript; available in PMC 2017 November 22. 


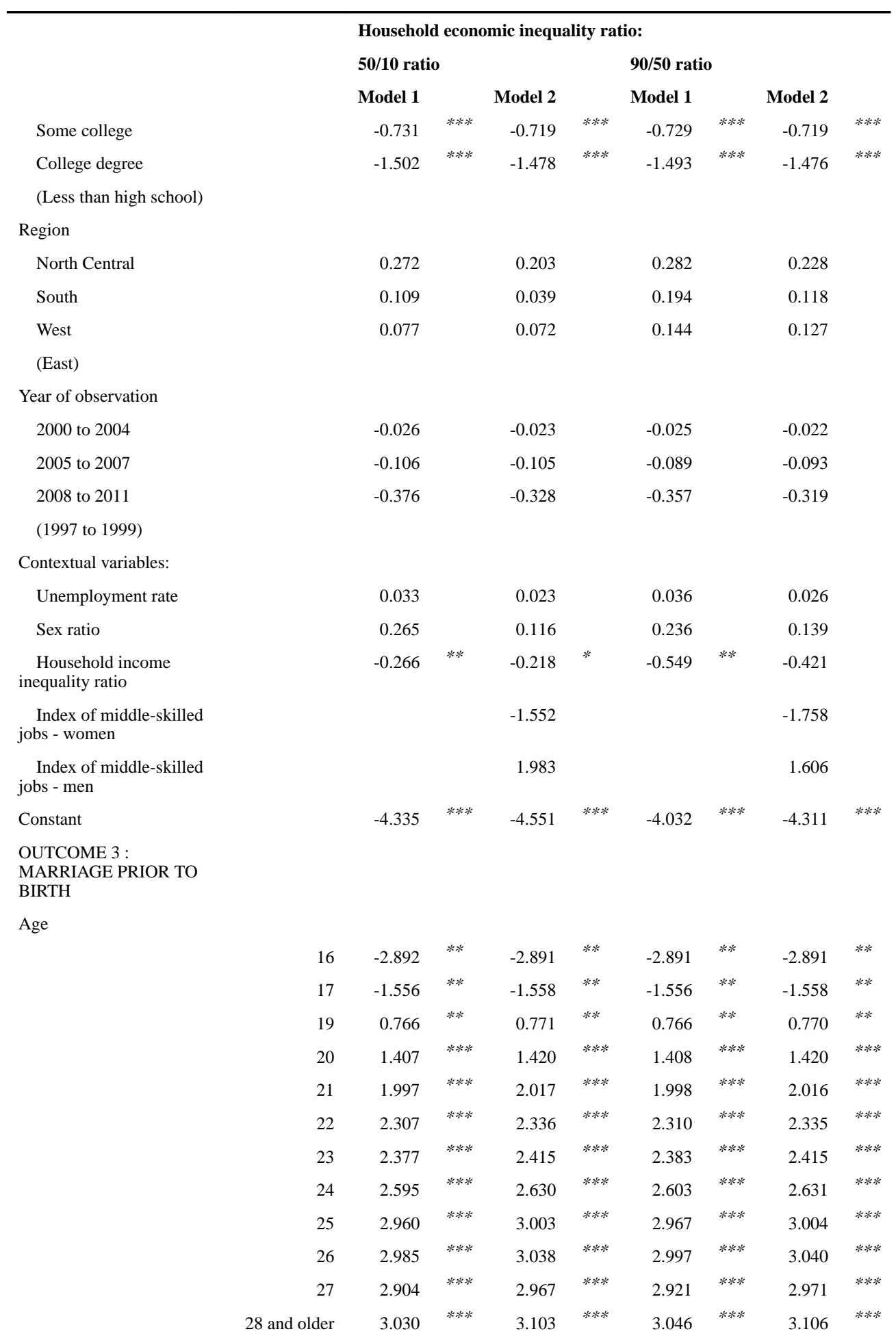

(18)

Race/Ethnicity

Black

$-0.706 \quad * * * \quad-0.719 \quad * * * \quad-0.716 \quad * * * \quad-0.724 \quad * * *$

Am Sociol Rev. Author manuscript; available in PMC 2017 November 22. 


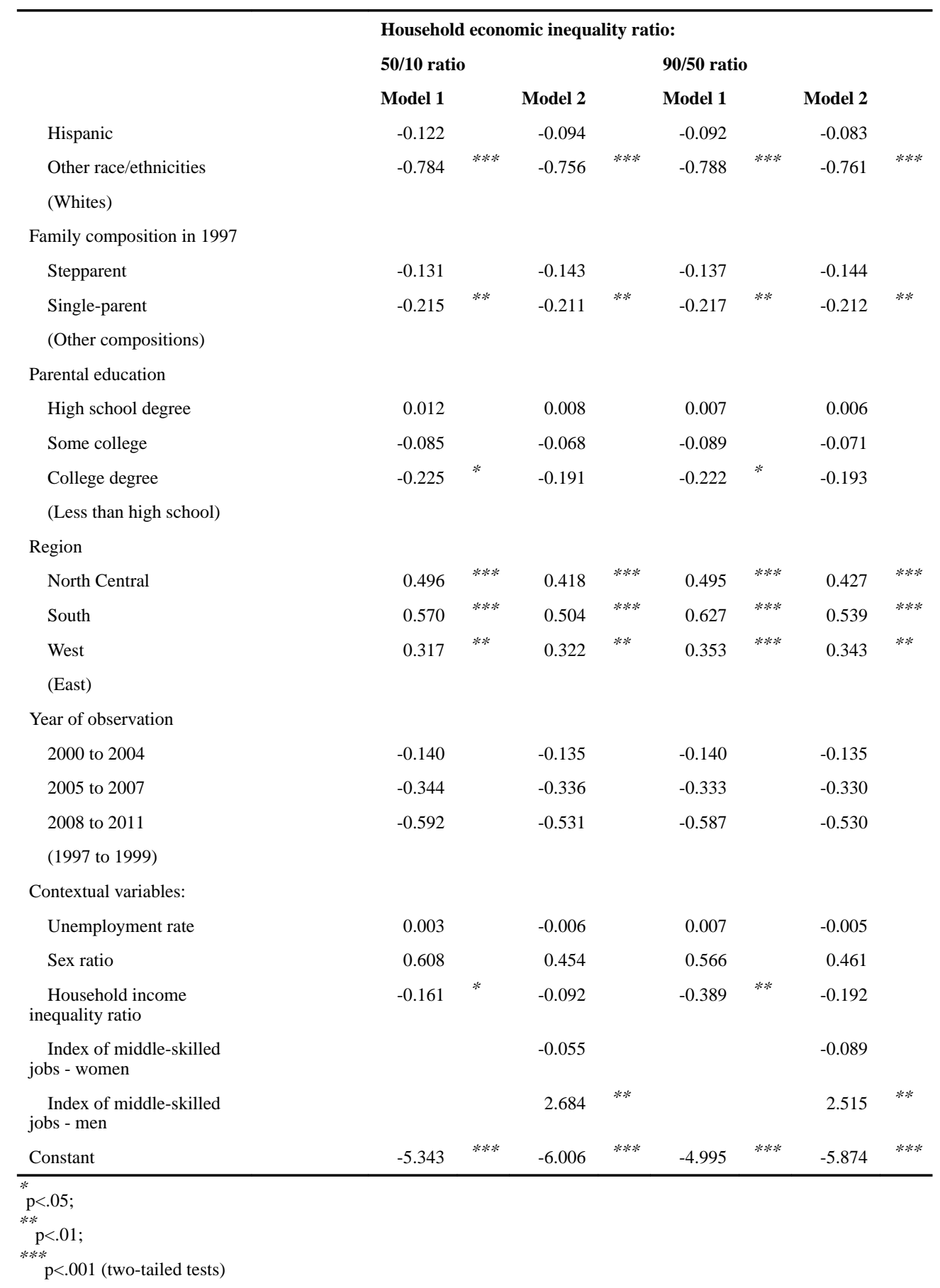

Am Sociol Rev. Author manuscript; available in PMC 2017 November 22. 


\section{Appendix Table 4}

Full parameter estimates from multinomial logistic hazard models with area of residence unconstrained: WOMEN. 50/10 90/50 (Reference categories in parentheses)

\begin{tabular}{|c|c|c|c|c|c|c|c|c|c|}
\hline \multirow{4}{*}{$\begin{array}{l}\text { OUTCOME 1: SINGLE } \\
\text { PARENT BIRTH }\end{array}$} & & \multicolumn{8}{|c|}{ Household economic inequality ratio: } \\
\hline & & \multicolumn{4}{|c|}{$50 / 10$ ratio } & \multicolumn{4}{|c|}{$90 / 50$ ratio } \\
\hline & & \multicolumn{2}{|l|}{ Model 1} & \multicolumn{2}{|l|}{ Model 2} & \multicolumn{2}{|l|}{ Model 1} & \multicolumn{2}{|l|}{ Model 2} \\
\hline & & & & & & & & & \\
\hline \multicolumn{10}{|l|}{ Age } \\
\hline & 16 & -0.535 & $* * *$ & -0.538 & $* * *$ & -0.536 & $* * *$ & -0.538 & $* * *$ \\
\hline & 17 & -0.260 & & -0.264 & & -0.261 & & -0.264 & \\
\hline & 19 & 0.176 & & 0.189 & & 0.179 & & 0.189 & \\
\hline & 20 & 0.245 & & 0.274 & $*$ & 0.252 & & 0.274 & $*$ \\
\hline & 21 & 0.216 & & 0.258 & & 0.222 & & 0.257 & \\
\hline & 22 & -0.041 & & 0.015 & & -0.031 & & 0.014 & \\
\hline & 23 & -0.149 & & -0.077 & & -0.134 & & -0.078 & \\
\hline & 24 & -0.266 & & -0.192 & & -0.249 & & -0.193 & \\
\hline & 25 & -0.422 & & -0.337 & & -0.404 & & -0.338 & \\
\hline & 26 & -0.654 & $*$ & -0.551 & & -0.634 & $*$ & -0.552 & \\
\hline & 27 & -0.322 & & -0.199 & & -0.295 & & -0.201 & \\
\hline & 28 and older & -1.319 & $* * *$ & -1.175 & $* * *$ & -1.290 & $* * *$ & -1.178 & $* * *$ \\
\hline \multicolumn{10}{|l|}{$(18)$} \\
\hline \multicolumn{10}{|l|}{ Race/Ethnicity } \\
\hline Black & & 1.006 & $* * *$ & 1.001 & $* * *$ & 1.006 & $* * *$ & 1.002 & $* * *$ \\
\hline Hispanic & & 0.682 & $* * *$ & 0.713 & $* * *$ & 0.704 & $* * *$ & 0.716 & $* * *$ \\
\hline Other race/ethnicities & & 0.109 & & 0.132 & & 0.110 & & 0.131 & \\
\hline \multicolumn{10}{|l|}{ (Whites) } \\
\hline \multicolumn{10}{|c|}{ Family composition in 1997} \\
\hline Stepparent & & 0.555 & $* * *$ & 0.538 & $* * *$ & 0.551 & $* * *$ & 0.538 & $* * *$ \\
\hline Single-parent & & 0.609 & $* * *$ & 0.606 & $* * *$ & 0.609 & $* * *$ & 0.606 & $* * *$ \\
\hline \multicolumn{10}{|l|}{ (Other compositions) } \\
\hline \multicolumn{10}{|l|}{ Parental education } \\
\hline High school degree & & -0.394 & $* * *$ & -0.389 & $* * *$ & -0.401 & $* * *$ & -0.391 & $* * *$ \\
\hline Some college & & -0.704 & $* * *$ & -0.683 & $* * *$ & -0.710 & $* * *$ & -0.686 & $* * *$ \\
\hline College degree & & -1.329 & $* * *$ & -1.287 & $* * *$ & -1.327 & $* * *$ & -1.288 & $* * *$ \\
\hline \multicolumn{10}{|l|}{ (Less than high school) } \\
\hline \multicolumn{10}{|l|}{ Region } \\
\hline North Central & & 0.177 & & 0.096 & & 0.155 & & 0.094 & \\
\hline South & & 0.155 & & 0.067 & & 0.167 & & 0.070 & \\
\hline West & & -0.198 & & -0.174 & & -0.180 & & -0.175 & \\
\hline
\end{tabular}




\begin{tabular}{|c|c|c|c|c|c|c|c|c|c|}
\hline & & \multicolumn{8}{|c|}{ Household economic inequality ratio: } \\
\hline & & \multicolumn{4}{|c|}{$50 / 10$ ratio } & \multicolumn{4}{|c|}{$\mathbf{9 0 / 5 0}$ ratio } \\
\hline & & Model 1 & & Model 2 & & Model 1 & & Model 2 & \\
\hline \multicolumn{10}{|l|}{ Year of observation } \\
\hline 2000 to 2004 & & -0.050 & & -0.049 & & -0.051 & & -0.049 & \\
\hline 2005 to 2007 & & -0.019 & & -0.004 & & -0.009 & & -0.003 & \\
\hline 2008 to 2011 & & 0.077 & & 0.154 & & 0.076 & & 0.150 & \\
\hline \multicolumn{10}{|l|}{ (1997 to 1999$)$} \\
\hline \multicolumn{10}{|l|}{ Contextual variables: } \\
\hline Unemployment rate & & 0.015 & & 0.004 & & 0.020 & & 0.005 & \\
\hline Sex ratio & & 0.042 & & -0.075 & & -0.033 & & -0.085 & \\
\hline $\begin{array}{l}\text { Household income } \\
\text { inequality ratio }\end{array}$ & & -0.078 & & -0.004 & & -0.293 & * & -0.045 & \\
\hline $\begin{array}{l}\text { Index of middle-skilled } \\
\text { jobs - women }\end{array}$ & & & & 3.967 & & & & 3.806 & \\
\hline $\begin{array}{l}\text { Index of middle-skilled } \\
\text { jobs - men }\end{array}$ & & & & 3.256 & $* *$ & & & 3.121 & $* *$ \\
\hline Constant & & -3.469 & $* * *$ & -4.861 & $* * *$ & -2.985 & $* * *$ & -4.707 & $* * *$ \\
\hline \multicolumn{10}{|l|}{$\begin{array}{l}\text { OUTCOME 2: } \\
\text { COHABITING BIRTH }\end{array}$} \\
\hline \multicolumn{10}{|l|}{ Age } \\
\hline & 16 & -1.531 & $* * *$ & -1.533 & $* * *$ & -1.531 & $* * *$ & -1.534 & $* * *$ \\
\hline & 17 & -0.516 & $*$ & -0.518 & $*$ & -0.519 & $*$ & -0.520 & * \\
\hline & 19 & 0.454 & $* *$ & 0.468 & $* *$ & 0.457 & $* *$ & 0.469 & $* *$ \\
\hline & 20 & 0.434 & $*$ & 0.464 & $*$ & 0.440 & * & 0.467 & * \\
\hline & 21 & 0.480 & $*$ & 0.525 & $* *$ & 0.486 & $*$ & 0.530 & $* *$ \\
\hline & 22 & 0.153 & & 0.211 & & 0.163 & & 0.218 & \\
\hline & 23 & 0.662 & *** & 0.739 & $* * *$ & 0.678 & $* *$ & 0.748 & $* * *$ \\
\hline & 24 & -0.042 & & 0.034 & & -0.027 & & 0.042 & \\
\hline & 25 & 0.023 & & 0.110 & & 0.042 & & 0.121 & \\
\hline & 26 & -0.070 & & 0.036 & & -0.047 & & 0.051 & \\
\hline & 27 & -0.412 & & -0.284 & & -0.374 & & -0.262 & \\
\hline & 28 and older & -0.139 & & 0.007 & & -0.101 & & 0.030 & \\
\hline \multicolumn{10}{|l|}{ (18) } \\
\hline \multicolumn{10}{|l|}{ Race/Ethnicity } \\
\hline Black & & -0.148 & & -0.155 & & -0.162 & & -0.169 & \\
\hline Hispanic & & 0.333 & $*$ & 0.352 & $*$ & 0.343 & * & 0.345 & * \\
\hline $\begin{array}{l}\text { Other race/ethnicities } \\
\text { (Whites) }\end{array}$ & & -0.111 & & -0.094 & & -0.115 & & -0.098 & \\
\hline \multicolumn{10}{|l|}{ Family composition in 1997} \\
\hline Stepparent & & 0.732 & $* * *$ & 0.718 & $* * *$ & 0.731 & $* * *$ & 0.721 & $* * *$ \\
\hline $\begin{array}{l}\text { Single-parent } \\
\text { (Other compositions) }\end{array}$ & & 0.588 & $* * *$ & 0.584 & $* * *$ & 0.587 & $* * *$ & 0.584 & $* * *$ \\
\hline \multicolumn{10}{|l|}{ Parental education } \\
\hline High school degree & & -0.437 & $* * *$ & -0.436 & $* * *$ & -0.441 & $* * *$ & -0.433 & $* * *$ \\
\hline
\end{tabular}

Am Sociol Rev. Author manuscript; available in PMC 2017 November 22. 


\begin{tabular}{|c|c|c|c|c|c|c|c|c|c|}
\hline & & \multicolumn{8}{|c|}{ Household economic inequality ratio: } \\
\hline & & \multicolumn{4}{|c|}{$50 / 10$ ratio } & \multicolumn{4}{|c|}{$90 / 50$ ratio } \\
\hline & & Model 1 & & Model 2 & & Model 1 & & Model 2 & \\
\hline Some college & & -0.744 & $* * *$ & -0.724 & $* * *$ & -0.746 & $* * *$ & -0.722 & *** \\
\hline $\begin{array}{l}\text { College degree } \\
\text { (Less than high school) }\end{array}$ & & -1.635 & $* * *$ & -1.595 & $* * *$ & -1.633 & $* * *$ & -1.593 & $* * *$ \\
\hline \multicolumn{10}{|l|}{ Region } \\
\hline North Central & & 0.023 & & -0.042 & & 0.050 & & -0.007 & \\
\hline South & & -0.098 & & -0.163 & & -0.021 & & -0.114 & \\
\hline $\begin{array}{l}\text { West } \\
\text { (East) }\end{array}$ & & -0.089 & & -0.058 & & -0.005 & & 0.003 & \\
\hline \multicolumn{10}{|l|}{ Year of observation } \\
\hline 2000 to 2004 & & 0.018 & & 0.020 & & 0.016 & & 0.019 & \\
\hline 2005 to 2007 & & 0.234 & & 0.261 & & 0.244 & & 0.263 & \\
\hline $\begin{array}{l}2008 \text { to } 2011 \\
\text { (1997 to } 1999)\end{array}$ & & 0.412 & & 0.493 & & 0.430 & & 0.510 & \\
\hline \multicolumn{10}{|l|}{ Contextual variables: } \\
\hline Unemployment rate & & 0.009 & & 0.003 & & 0.007 & & -0.003 & \\
\hline Sex ratio & & 1.012 & & 1.024 & & 1.054 & & 1.113 & \\
\hline $\begin{array}{l}\text { Household income } \\
\text { inequality ratio }\end{array}$ & & -0.266 & $* *$ & -0.186 & & -0.504 & $* *$ & -0.237 & \\
\hline $\begin{array}{l}\text { Index of middle-skilled } \\
\text { jobs - women }\end{array}$ & & & & 6.597 & $*$ & & & 6.549 & $*$ \\
\hline $\begin{array}{l}\text { Index of middle-skilled } \\
\text { jobs - men }\end{array}$ & & & & 3.383 & $* *$ & & & 3.438 & * \\
\hline Constant & & -3.904 & $* * *$ & -5.870 & $* * *$ & -3.758 & $* * *$ & -6.114 & $* * *$ \\
\hline \multicolumn{10}{|l|}{$\begin{array}{l}\text { OUTCOME } 3 \text { : } \\
\text { MARRIAGE PRIOR TO } \\
\text { BIRTH }\end{array}$} \\
\hline \multicolumn{10}{|l|}{ Age } \\
\hline & 16 & -2.628 & $* * *$ & -2.627 & $* * *$ & -2.626 & $* * *$ & -2.626 & $* * *$ \\
\hline & 17 & -0.968 & $* * *$ & -0.968 & $* * *$ & -0.969 & $* * *$ & -0.969 & $* * *$ \\
\hline & 19 & 0.734 & $* * *$ & 0.744 & $* * *$ & 0.737 & $* * *$ & 0.745 & $* * *$ \\
\hline & 20 & 0.998 & $* * *$ & 1.020 & $* * *$ & 1.004 & $* * *$ & 1.023 & $* * *$ \\
\hline & 21 & 1.393 & $* * *$ & 1.427 & $* * *$ & 1.398 & $* * *$ & 1.429 & $* * *$ \\
\hline & 22 & 1.257 & $* * *$ & 1.300 & $* * *$ & 1.263 & $* * *$ & 1.301 & $* * *$ \\
\hline & 23 & 1.598 & $* * *$ & 1.656 & $* * *$ & 1.609 & $* * *$ & 1.659 & $* * *$ \\
\hline & 24 & 1.491 & $* * *$ & 1.551 & $* * *$ & 1.504 & $* * *$ & 1.555 & $* * *$ \\
\hline & 25 & 1.841 & $* * *$ & 1.907 & $* * *$ & 1.856 & $* * *$ & 1.911 & $* * *$ \\
\hline & 26 & 1.724 & $* * *$ & 1.806 & $* * *$ & 1.742 & $* * *$ & 1.812 & $* * *$ \\
\hline & 27 & 1.849 & $* * *$ & 1.943 & $* * *$ & 1.878 & $* * *$ & 1.956 & $* * *$ \\
\hline & 28 and older & 1.975 & $* * *$ & 2.081 & $* * *$ & 2.003 & $* * *$ & 2.090 & $* * *$ \\
\hline
\end{tabular}

Race/Ethnicity

Black

$-1.068 \quad * * * \quad-1.084 \quad * * * \quad-1.077 \quad * * * \quad-1.092 \quad * * *$

Am Sociol Rev. Author manuscript; available in PMC 2017 November 22. 


\begin{tabular}{|c|c|c|c|c|c|c|c|c|}
\hline & \multicolumn{8}{|c|}{ Household economic inequality ratio: } \\
\hline & \multicolumn{4}{|c|}{$50 / 10$ ratio } & \multicolumn{4}{|c|}{$\mathbf{9 0 / 5 0}$ ratio } \\
\hline & Model 1 & & Model 2 & & Model 1 & & Model 2 & \\
\hline Hispanic & -0.172 & & -0.164 & & -0.152 & & -0.157 & \\
\hline $\begin{array}{l}\text { Other race/ethnicities } \\
\text { (Whites) }\end{array}$ & -0.631 & $* * *$ & -0.617 & $* * *$ & -0.636 & $* * *$ & -0.623 & $* * *$ \\
\hline \multicolumn{9}{|l|}{ Family composition in 1997} \\
\hline Stepparent & 0.047 & & 0.035 & & 0.048 & & 0.038 & \\
\hline $\begin{array}{l}\text { Single-parent } \\
\text { (Other compositions) }\end{array}$ & -0.108 & & -0.115 & & -0.110 & & -0.114 & \\
\hline \multicolumn{9}{|l|}{ Parental education } \\
\hline High school degree & -0.144 & & -0.145 & & -0.156 & & -0.151 & \\
\hline Some college & -0.249 & $*$ & -0.235 & * & -0.256 & $* *$ & -0.241 & * \\
\hline $\begin{array}{l}\text { College degree } \\
\text { (Less than high school) }\end{array}$ & -0.313 & $* *$ & -0.281 & $* *$ & -0.318 & $* *$ & -0.288 & $* *$ \\
\hline \multicolumn{9}{|l|}{ Region } \\
\hline North Central & 0.327 & $* *$ & 0.289 & $* *$ & 0.345 & $* * *$ & 0.320 & $* *$ \\
\hline South & 0.707 & $* * *$ & 0.678 & $* * *$ & 0.788 & $* * *$ & 0.747 & $* * *$ \\
\hline $\begin{array}{l}\text { West } \\
\text { (East) }\end{array}$ & 0.254 & $*$ & 0.278 & $* *$ & 0.319 & $* *$ & 0.332 & $* *$ \\
\hline \multicolumn{9}{|l|}{ Year of observation } \\
\hline 2000 to 2004 & -0.204 & & -0.199 & & -0.206 & & -0.200 & \\
\hline 2005 to 2007 & -0.171 & & -0.145 & & -0.160 & & -0.140 & \\
\hline $\begin{array}{l}2008 \text { to } 2011 \\
\text { (1997 to } 1999 \text { ) }\end{array}$ & -0.370 & & -0.305 & & -0.360 & & -0.301 & \\
\hline \multicolumn{9}{|l|}{ Contextual variables: } \\
\hline Unemployment rate & 0.021 & & 0.017 & & 0.022 & & 0.016 & \\
\hline Sex ratio & 1.634 & $* *$ & 1.636 & $* *$ & 1.693 & $* * *$ & 1.718 & $* * *$ \\
\hline $\begin{array}{l}\text { Household income } \\
\text { inequality ratio }\end{array}$ & -0.260 & $* * *$ & -0.204 & $* *$ & -0.509 & $* * *$ & -0.350 & * \\
\hline $\begin{array}{l}\text { Index of middle-skilled } \\
\text { jobs - women }\end{array}$ & & & 5.952 & $* *$ & & & 5.872 & $* *$ \\
\hline $\begin{array}{l}\text { Index of middle-skilled } \\
\text { jobs - men }\end{array}$ & & & 2.258 & $* *$ & & & 2.021 & $*$ \\
\hline Constant & -4.757 & $* * *$ & -6.293 & $* * *$ & -4.602 & $* * *$ & -6.268 & $* * *$ \\
\hline $\begin{array}{l}\text { p }<.05 ; \\
* * * 01 \\
\text { p }<.01 \\
\text { p }<.001 \text { (two-tailed tests) }\end{array}$ & & & & & & & & \\
\hline
\end{tabular}

\section{References}

Allison, Paul D. Discrete-Time Methods for the Analysis of Event Histories. Sociological methodology. 1982; 13(1):61-98.

Arroyo, Julia, Payne, Krista K., Brown, Susan L., Manning, Wendy D. Crossover in Median Age at First Marriage and First Birth: Thirty Years of Change. National Center for Marriage and Family 
Research, Family Profile-12-03. 2012. Retrieved August 22, (http://ncfmr.bgsu.edu/pdf/ family_profiles/file129368.pdf)

Autor, David. The Polarization of Job Opportunities in the U.S. Labor Market: Implications for Employment and Earnings. Brookings Institution: The Hamilton Project. 2010. Retrieved May 23, 2014 (http://www.brookings.edu/ /media/Files/rc/papers/2010/04_jobs_autor/04_jobs_autor.pdf)

Autor, David H., Katz, Lawrence F., Kearney, Melissa S. Trends in U.S. Wage Inequality: Revising the Revisionists. Review of Economics and Statistics. 2008; 90(2):300-23.

Autor, David H., Dorn, David, Hanson, Gordon H. The China Syndrome: Local Labor Market Effects of Import Competition in the United States. American Economic Review. 2013; 103(6):2121-68.

Bachrach, Christine A., Newcomer, Susan. Forum: Intended Pregnancies and Unintended Pregnancies: Distinct Categories or Opposite Ends of a Continuum? Family Planning Perspectives. 1999; 31(5): 251. [PubMed: 10723654]

Card, David, DiNardo, John E. Skill-Biased Technological Change and Rising Wage Inequality: Some Problems and Puzzles. Journal of Labor Economics. 2002; 20(4):733-83.

Carlson, Marcia J., VanOrman, Alicia G., Pilkauskas, Natasha V. Examining the Antecedents of U.S. Nomarital Fatherhood. Demography. 2013; 50:1421-47. [PubMed: 23576263]

Cherlin, Andrew J. The Marriage-Go-Round: The State of Marriage and the Family in America Today. New York: Alfred A. Knopf; 2009.

Cherlin, Andrew J. Demographic Trends in the United States: A Review of Research in the 2000s. Journal of Marriage and Family. 2010; 72(3):402-19.

Cherlin, Andrew J., Talbert, Elizabeth, Yasutake, Suzumi. Annual Meeting of the Population Association of America. Boston: 2014 May 3. Changing Fertility Regimes and Transitions to Adulthood: Evidence from a Recent Cohort. 2014

Edin, Kathryn, Kefalas, Maria J. Promises I Can Keep: Why Poor Women Put Motherhood before Marriage. Berkeley: University of California Press; 2005.

England, Paula. Sometimes the Social Becomes Personal: Gender, Class. And Sexualities. Paper presented at the American Sociological Association; August 23, 2015; Chicago. 2015.

Frank, Robert H., Levine, Adam Seth, Dijk, Oege. Expenditure Cascades. Review of Behavioral Economics. 2014; 1:55-73.

Gelman, Andrew, Kenworthy, Lane, Su, Yu-Sung. Income Inequality and Partisan Voting in the United States. Social science quarterly. 2010; 91(5):1203-19.

Gold, Rachel, Kawachi, Ichiro, Kennedy, Bruce P., Lynch, John W., Connell, Frederick A. Ecological Analysis of Teen Birth Rates: Association with Community Income and Income Inequality. Maternal and child health journal. 2001; 5(3):161-67. [PubMed: 11605721]

Gould, Eric D., Paserman, M Daniele. Waiting for Mr. Right: Rising Inequality and Declining Marriage Rates. Journal of Urban Economics. 2003; 53:257-81.

Hayford, Sarah R., Morgan, S Philip. The Quality of Retrospective Data on Cohabitation. Demography. 2008; 45:129-41. [PubMed: 18390295]

Hofferth, Sandra L., Goldscheider, Frances. Family Structure and the Transition to Early Parenthood. Demography. 2010; 47(2):415-37. [PubMed: 20608104]

Kalleberg, Arne L. Bad Jobs: The Rise of Polarized and Precarious Employment Systems in the United States, 1970s to 2000s. New York: Russell Sage Foundation; 2011.

Kearney, Melissa S., Levine, Phillip B. Income Inequality and Early Nonmarital Childbearing. Journal of Human Resources. 2014a; 49(1):1-31.

Kearney, Melissa S., Levine, Phillip B. NBER Working Paper 20195. Cambridge MA: National Bureau of Economic Research; 2014b. Income Inequality, Social Mobility, and the Decision to Drop out of High School.

Kristal, Tali. The Capitalist Machine: Computerization, Workers' Power, and the Decline in Labor's Share within US Industries. American Sociological Review. 2013; 78(3):361-89.

Lin, Ken-Hou, Tomaskovic-Devey, Donald. Financialization and US Income Inequality, 1970-20081. American Journal of Sociology. 2013; 118(5):1284-329.

Loughran, David S. The Effect of Male Wage Inequality on Female Age at First Marriage. Review of Economics and Statistics. 2002; 84(2):237-50. 
McLaughlin, Diane K., Stokes, C Shannon, Nonoyama, Atsuko. Residence and Income Inequality: Effects on Mortality among US Counties. Rural Sociology. 2001; 66(4):579-98.

McLaughlin, Diane K., Lichter, Daniel T. Poverty and the Marital Behavior of Young Women. Journal of Marriage and the Family. 1997; 59:582-94.

Moller, Stephanie, Alderson, Arthur S., Nielsen, Francois. Changing Patterns of Income Inequality in US Counties, 1970-20001. American Journal of Sociology. 2009; 114:1037-101.

National Bureau of Economic Research. Business Cycle Dating Committee. Cambridge MA: 2010. Retrieved November 9, 2015 (http://www.nber.org/cycles/sept2010.html)

Oppenheimer, Valerie Kincade. A Theory of Marriage Timing. American Journal of Sociology. 1988; 94:563-91.

Oppenheimer, Valerie Kincade, Blossfeld, Hans-Peter, Wackerow, Achim. United States of America. In: Blossfeld, HP., editor. The New Role of Women: Family Formation in Modern Societies. Boulder, CO: Westview Press; 1995. p. 150-73.

Oppenheimer, Valerie Kincade, Kalmijn, Matthjis, Lim, Nelson. Men's Career Development and Marriage Timing During a Period of Rising Inequality. Demography. 1997; 34(3):311-30. [PubMed: 9275242]

Payne, Krista K., Manning, Wendy D., Brown, Susan L. Unmarried Births to Cohabiting and Single Mothers, 2005-2010. National Center for Family and Marriage Research, Family Profile FP-12-06. 2012. Retrieved August 14, 2013 (http://ncfmr.bgsu.edu/pdf/family_profiles/file109171.pdf)

Pew Research Center. Millennnials: A Portrait of Generation Next. 2010. Retrieved March 21, 2014 (http://www.pewsocialtrends.org/files/2010/10/millennials-confident-connected-open-tochange.pdf)

Pew Research Center. Record Share of Americans Have Never Married. 2014. Retrieved October 9, 2014 (http://www.pewsocialtrends.org/2014/09/24/record-share-of-americans-have-never-married/ \#what-never-married-adults-are-looking-for-in-a-potential-spouse)

Pickett, Kate, Wilkinson, Richard. The Spirit Level: Why Greater Equality Makes Societies Stronger. London: Allen Lane; 2009.

Piketty, Thomas, Saez, Emmanuel. Income Inequality in the United States, 1913-1998. The Quarterly Journal of Economics. 2003; 118(1):1-41.

Qian, Zhenchao, Lichter, Daniel T. Changing Patterns of Interracial Marriage in a Multiracial Society. Journal of Marriage and Family. 2011; 73:1065-84.

Rackin, Heather, Gibson-Davis, Christina M. The Role of Pre- and Postconception Relationships for First-Time Parents. Journal of Marriage and Family. 2012; 74(3):526-39.

Reed, Joanna, England, Paula, Littlejohn, Krystale, Bass, Brooke Conroy, Caudillo, Mónica L. Consistent and Inconsistent Contraception among Young Women: Insights from Qualitative Interviews. Family Relations. 2014; 63(2):244-58.

Reed, Joanna M. Not Crossing the "Extra Line": How Cohabitors with Children View Their Unions. Journal of Marriage and Family. 2006; 68:1117-31.

Robinson WS. Ecological Correlations and the Behavior of Individuals. American Sociological Review. 1950; 15(3):351-57.

Rose-Greenland, Fiona, Smock, Pamela J. Living Together Unmarried: What Do We Know About Cohabiting Families?. In: Peterson, GW., Bush, KR., editors. Handbook of Marriage and the Family. New York: Springer; 2013. p. 255-73.

Ruggles, Steven, Alexander, J Trent, Genadek, Katie, Goeken, Ronald, Schroeder, Matthew B., Sobek, Matthew. Integrated Public Use Microdata Series: Version 5.0 [Machine-Readable Database]. Minnesota Population Center. 2010

Schwartz, Christine R. Trends and Variation in Assortative Mating: Causes and Consequences. Annual Review of Sociology. 2013; 39:451-70.

Selvin, Hanan C. Durkheim's Suicide and the Problems of Empirical Research. American Journal of Sociology. 1958; 63(6):607-19.

Stykes, Bart, Williams, Seth. Diverging Destinies: Children's Family Structure Variation by Maternal Education. National Center for Family and Marriage Research, FP-13-16. 2013. Retrieved October 30, 2013 (http://ncfmr.bgsu.edu/pdf/family_profiles/file134877.pdf) 
Sweeney, Megan M., Raley, R Kelly. Race, Ethnicity, and the Changing Context of Childbearing in the United States. Annual Review of Sociology. 2014; 40:539-58.

U.S. Bureau of the Census. History of Public Use Microdata Areas (Pumas): 1960-2000. 2013. Retrieved August 18, 2015 (http://www2.census.gov/geo/pdfs/reference/puma/puma_history.pdf)

U.S. National Center for Health Statistics. Nonmarital Childbearing in the United States, 1940 - 1999. National Vital Statistics Reports. 2000; 48(16) Retrieved February 4, 2009 (http://www.cdc.gov/ nchs/data/nvsr/nvsr48/nvs48_16.pdf).

U.S. National Center for Health Statistics. Fertility of Men and Women Aged 15-44 Years in the United States: National Survey of Family Growth, 2006-2010. National Health Statistics Reports. 2012; (51)

U.S. National Center for Health Statistics. Births: Final Data for 2013. National Vital Statistics Reports. 2015; 64(1) (http://www.cdc.gov/nchs/data/nvsr/nvsr64/nvsr64_01.pdf).

Vogli, Roberto De, Kouvonen, Anne, Elovainio, Marko, Marmot, Michael. Economic Globalization, Inequality and Body Mass Index: A Cross-National Analysis of 127 Countries. Critical Public Health. 2014; 24(1):7-21.

Western, Bruce, Rosenfeld, Jake. Unions, Norms, and the Rise in US Wage Inequality. American Sociological Review. 2011; 76(4):513-37.

Wilson, William Julius. The Truly Disadvantaged: The Inner City, the Underclass, and Public Policy. Chicago: University of Chicago Press; 1987. 


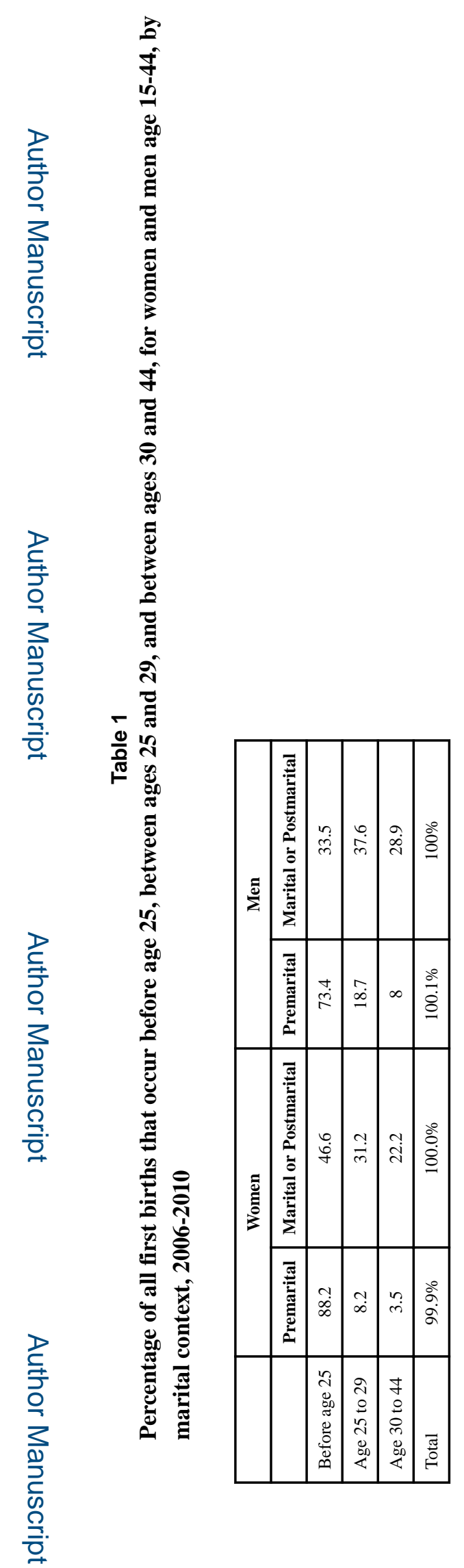

Am Sociol Rev. Author manuscript; available in PMC 2017 November 22. 


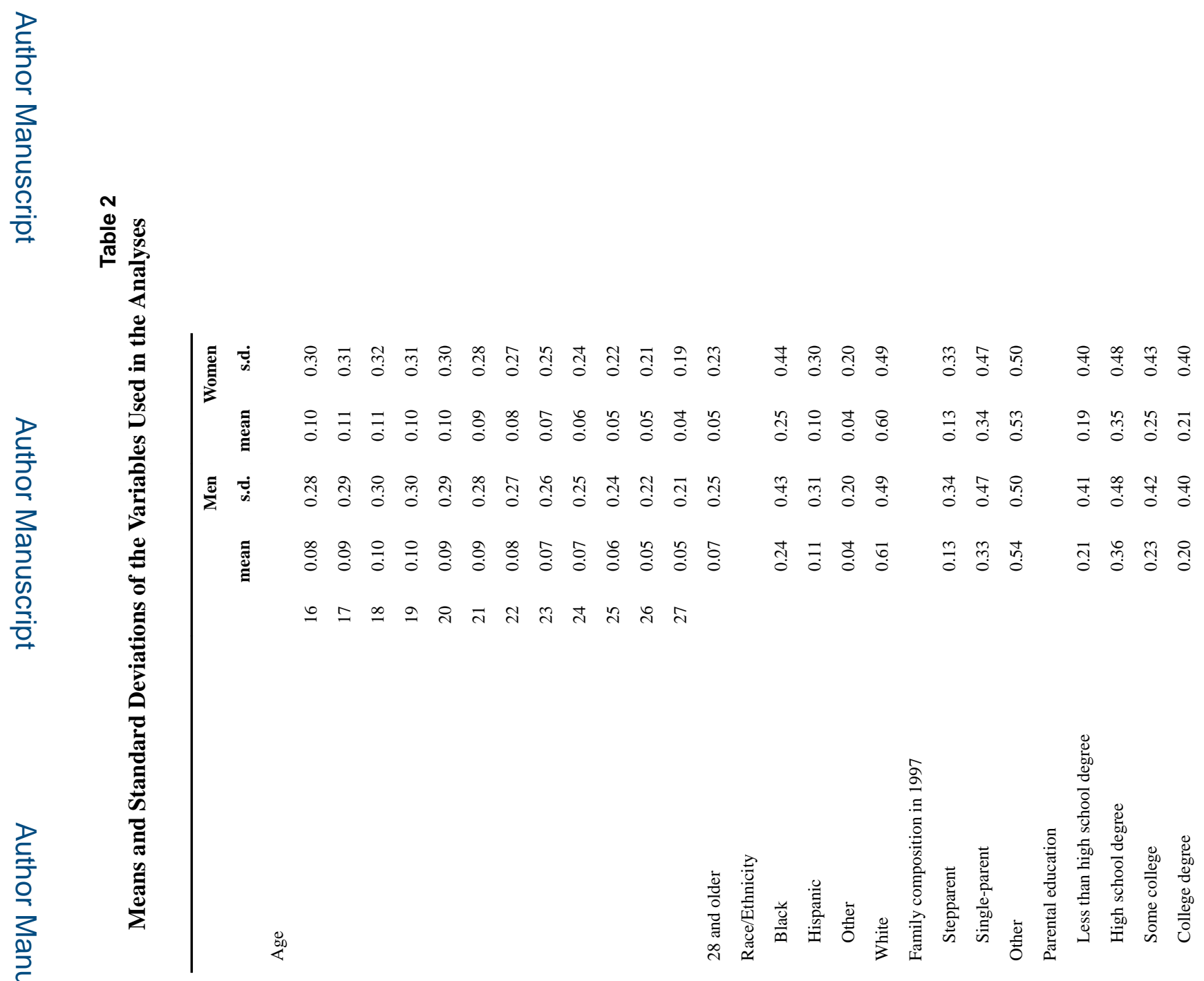




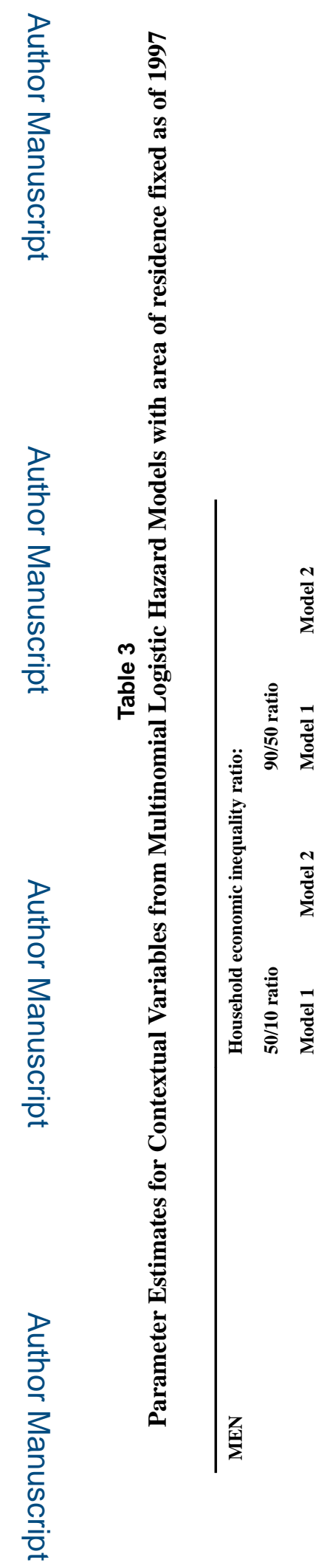

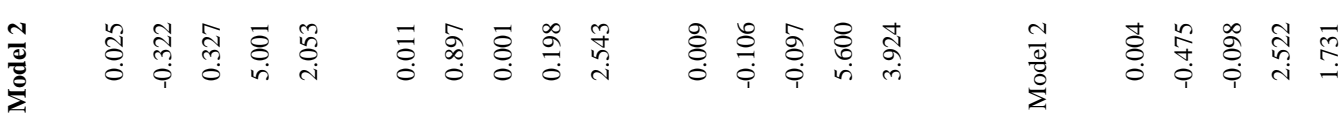

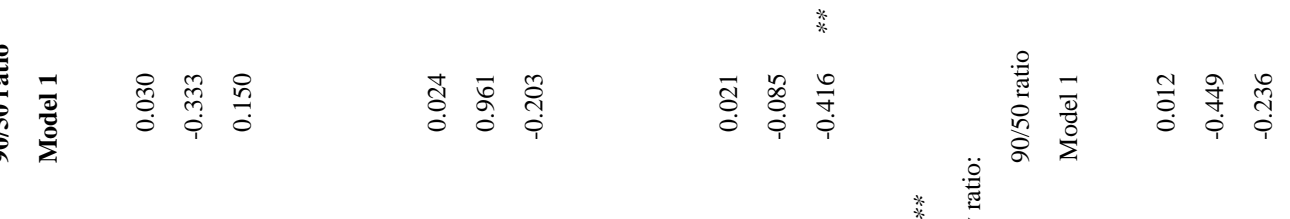

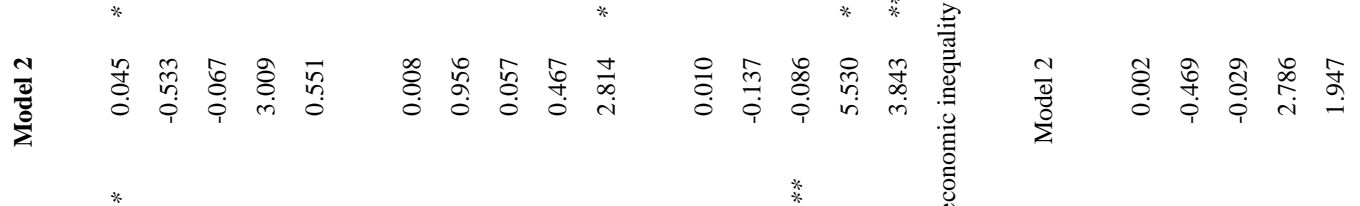

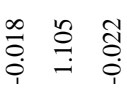

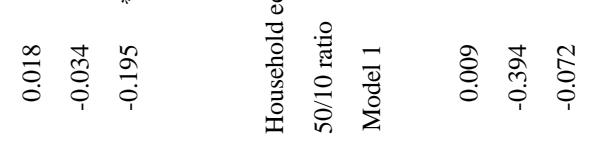

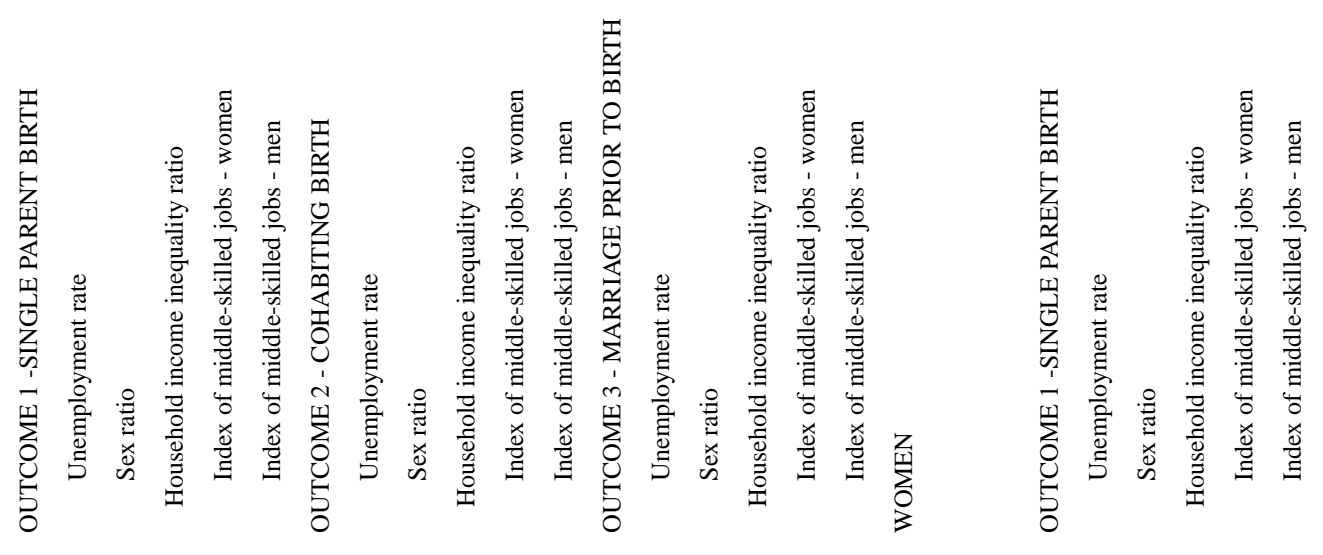


Cherlin et al.

Page 41

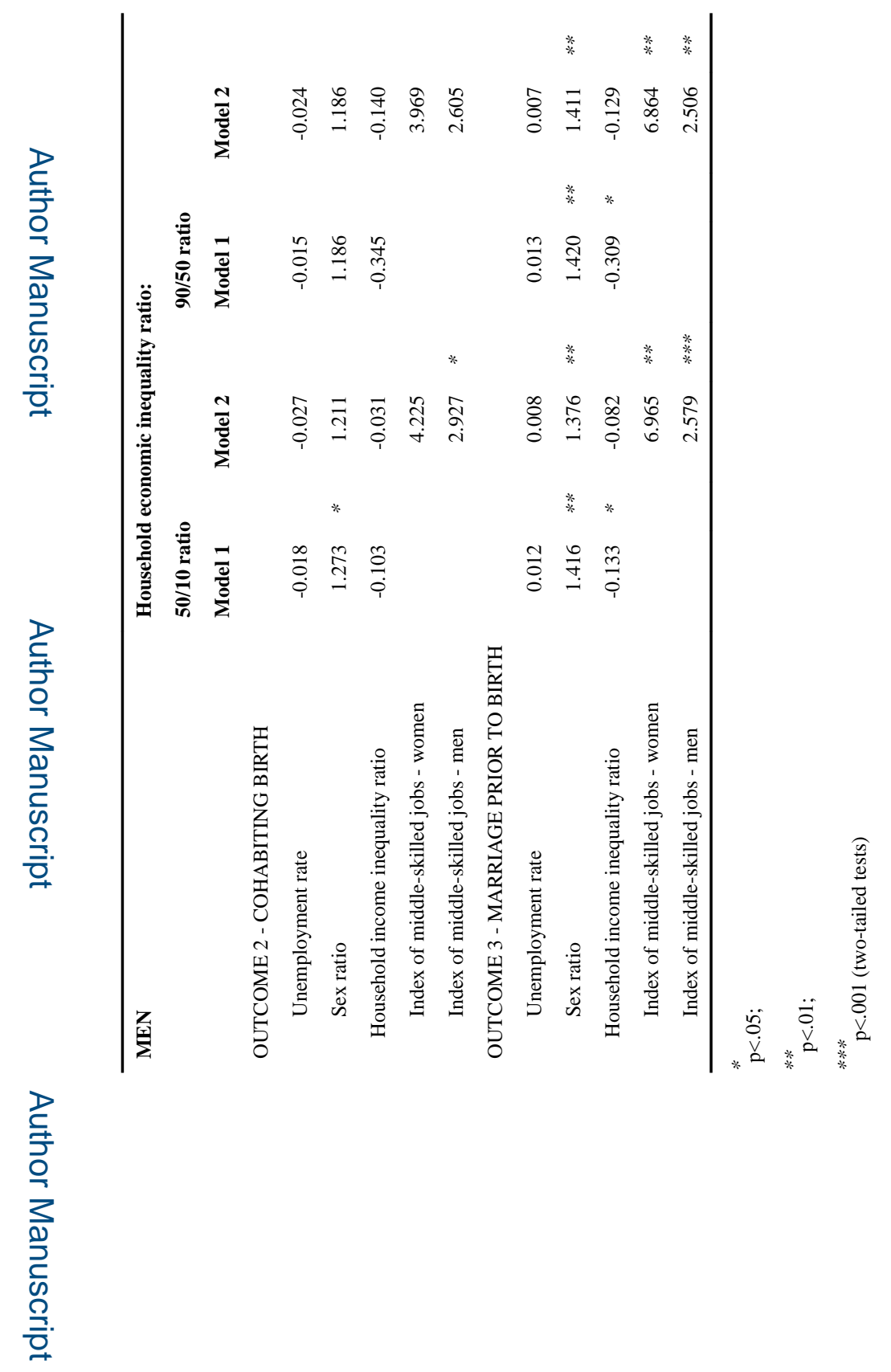

로을

Am Sociol Rev. Author manuscript; available in PMC 2017 November 22. 


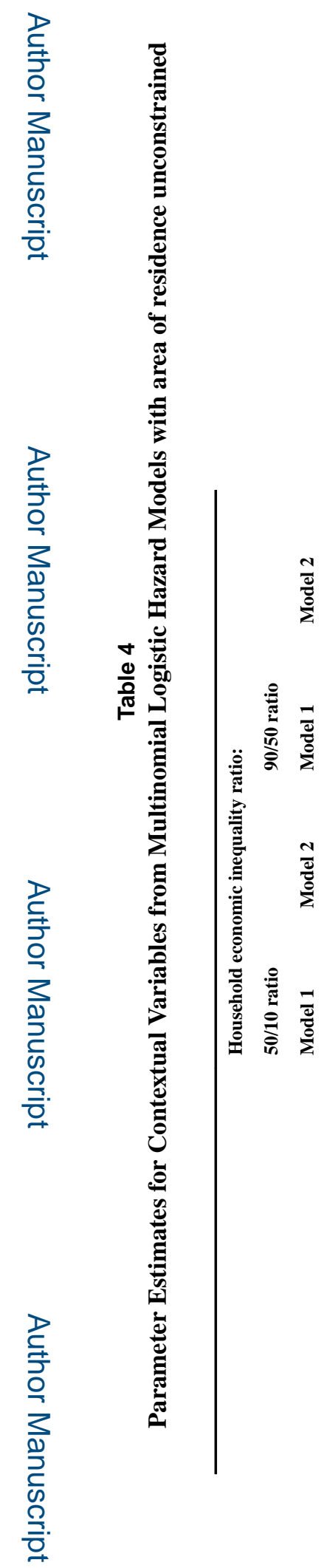

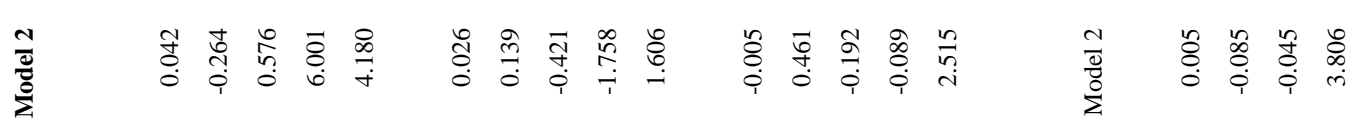

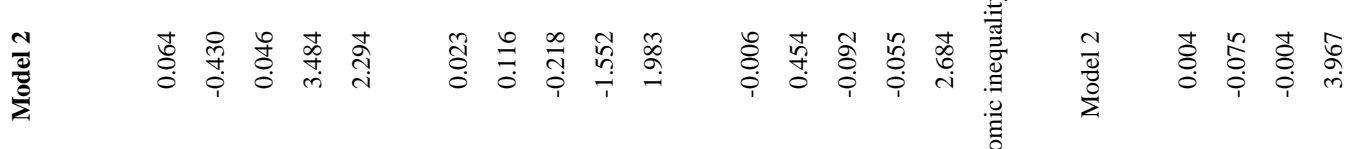

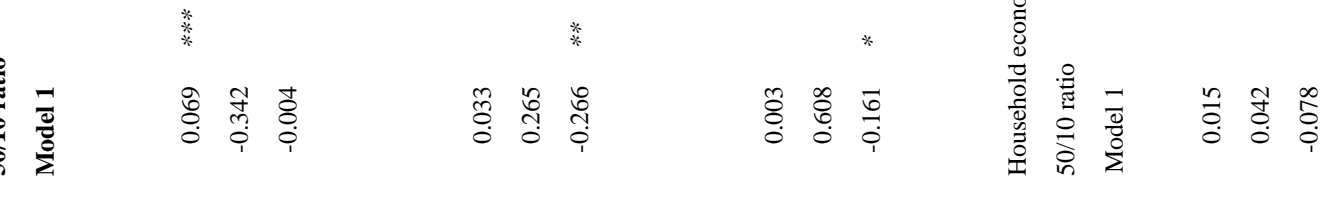

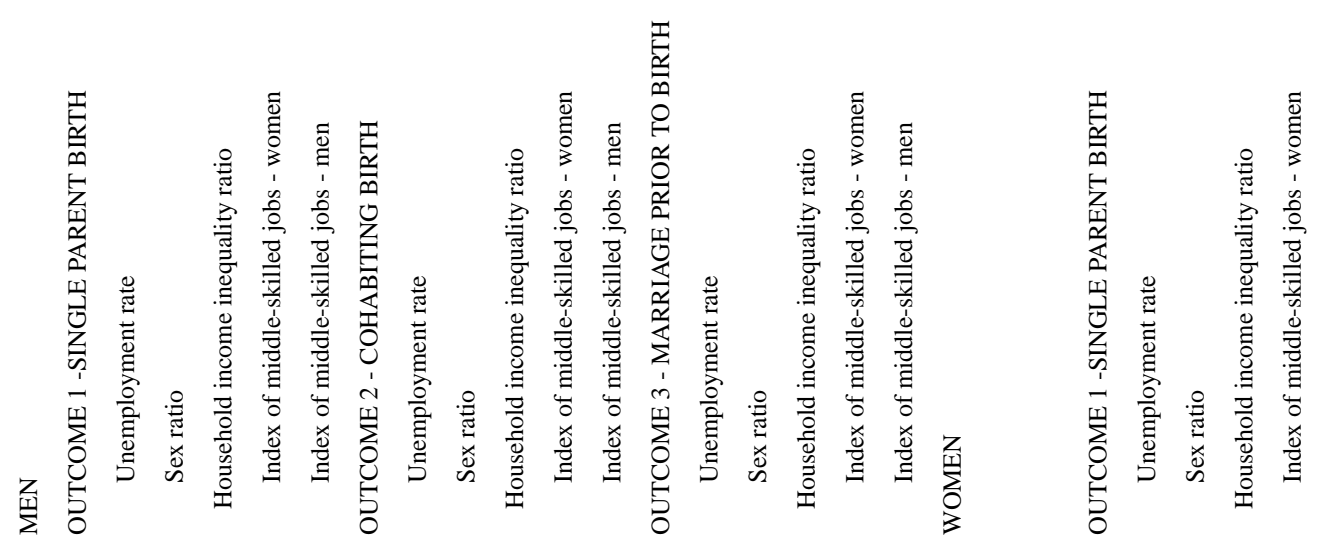
Am Sociol Rev. Author manuscript; available in PMC 2017 November 22. 


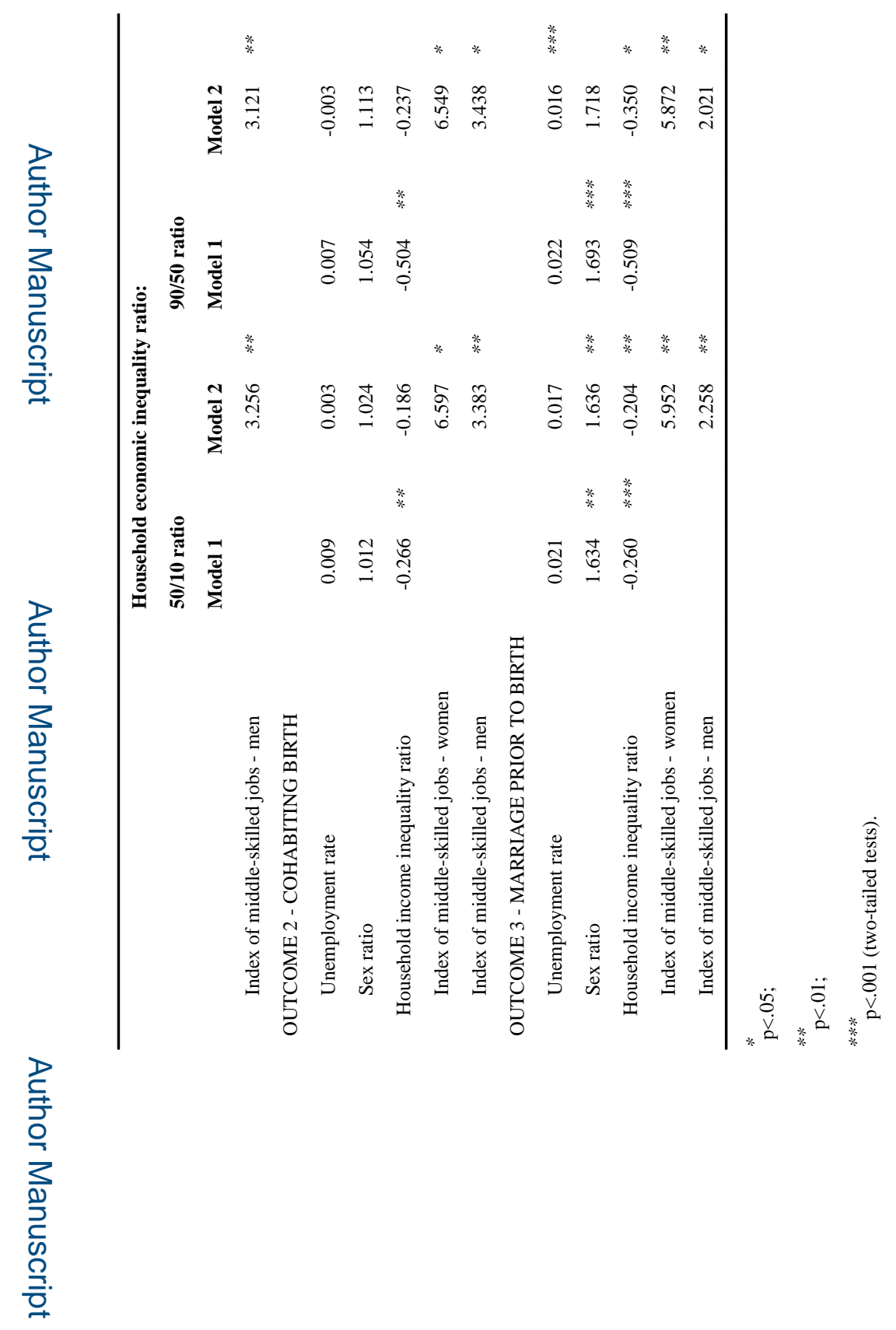

로을

Am Sociol Rev. Author manuscript; available in PMC 2017 November 22. 